\title{
Impact Assessment of Environmental Law on the Administrative Costs of Enterprises Using SCM Methodology: A Case Study
}

\author{
Maria do Céu Colaço dos Santos \\ Center of Administration and Public Policies (CAPP), Institute of Social and Political \\ Science, Lisbon University (ISCSP-UL), Portugal
}

João Abreu de Faria Bilhim

Center of Administration and Public Policies (CAPP), Institute of Social and Political Science, Lisbon University (ISCSP-UL), Portugal

Received: July 2, 2018 Accepted: August 3, 2018 Online published: August 14, 2018

doi:10.5296/jpag.v8i3.13505 URL: https://doi.org/10.5296/jpag.v8i3.13505

\begin{abstract}
The regulatory reforms initiated by the international and national bodies aim for a "better regulation", "better policies for a better life" and "better policies for sustainable development". In this sense, better regulatory activity abides by a set of principles that makes it a "good-quality regulation". A better regulation is one which reaches its purposes at a reduced cost. The cost-benefit analysis has been an exercise adopted by the international and national bodies for the evaluation of the impact of the law. A systematic analysis of the impact is encouraged, on an ex-ante and ex-post cycle of the legislative process, with the purpose of diagnosing and reducing the unnecessary charges for companies and citizens. In this context, this work offers an investigation of the impact of the environmental law on the administrative costs of Portuguese companies, applying the standard cost model (SCM) methodology. We concluded that the administrative charges for the companies arising from the time spent on the fulfilment of information obligations resulting from the law exceed what is acceptable and that this spent time encompasses the irritation costs and lost opportunities for companies. Environmental licences impose many legal requirements for the protection of soil, air and water and encompass a diversified set of competent public authorities that share the monitoring and regulation of the covered economic activities, contributing to the massification of bureaucracy and, consequently, to the administrative costs.
\end{abstract}


Keywords: better regulation, sustainability, environmental law, SCM, administrative costs

\section{Introduction}

A set of standards and rules - laws - connect the government and society and regulate the behaviour of economic agents and citizens. People need rules and regulations as do companies which many times act as mediators on the population's well-being. First and foremost, the regulatory powers are a task of the government as the superior body of public administration. Public regulation of the economy covers access to economic activity, affecting or restraining freedom of economic enterprise and competition, in defence of the functioning of the market and of the consumers (Marques, 2017). Core regulatory reform at the turn of the millennium illustrates systematic State intervention in society. Interdependency of economic agents safeguards the general public's interests, such as the protection of natural resources, protection of employees, company's creative and innovative potential, job creation and better quality of life. Regulatory reform of regulatory policies protects and promotes the population's social and economic development, through proportional requirements, transparent information, quality control and process efficiency (Arndt, Baker, Querbach, \& Schultz, 2015; OECD, 2015; WBG, 2016). Nevertheless, new regulations entail costs for adjustments or modified behaviours of the agents to fulfil their duties. The quality and efficiency of the law is evaluated on a cost-benefit relation. A cost is "any item that makes the person worse or reduces his/her well-being, and this includes the opportunities lost through the implementation of a specific political measure" (Renda, Schrefler, Luchetta, \& Zavatta, 2013: p.22). In turn, efficiency relies on resources used to achieve the law's purpose (which entails resource expenditure for the State and/or for agents assigned by regulation).

The OECD (2015; p.23) offers the following definition: "the regulatory quality is evaluated through the development, cost-benefit, legal quality and the administrative formalities. This definition of regulatory quality covers the processes, i.e., regulations that are effective in meeting their goals, efficiency (that does not impose unnecessary costs), coherence (when the total scope of the regulatory regime is considered) and simplicity (the regulation in itself and the rules for its implementation should be clear and easy to understand)".

The analysis of the regulation's impact has been widespread and recommended by the international bodies (i.e., OECD, EC), to promote better policies that lead to sustainable and inclusive development and growth. In this context, the regulation's implications for the companies have paralleled the regulatory reform's problematics. If, on the one hand, economic development and foreign investment are desirable, then, on the other hand, private action is limited and capital is restrained, moving business investment to more politically favourable environments.

This work envisages the evaluation of the impact of "environmental law" on the administrative costs of Portuguese companies, using the standard cost model methodology (SCM). SCM is a methodology broadly recommended by the EU and commonly accepted by the Member States, and it measures the regulation's administrative costs, i.e., the costs for fulfilment of legal duties. By executing this evaluation, we are contributing to the further 


\section{Macrothink Institute $^{\mathrm{TM}}$}

knowledge of this methodology's potential, in the sense of the use and exercise of the SCM, as well as the results of its applications, being publicly unknown. On the other hand, we uncover the implications of the environmental policies on business life and remit for political and public awareness the consequences for sustainable development and growth.

\section{Literature Review}

\subsection{Regulation and Regulatory Reform: The Primacy of Quality and Efficiency}

The regulatory reform highlights the quality and efficiency of the regulatory policies as the driving force for economic prosperity and the social well-being of nations.

Quality refers to the costs-benefits balance of the adoption of a certain regulation and its implementation, considering both political purpose and public interest. Efficiency is the entire production which leads to quality measurement, or non-conformity with the purpose and impact on the intended results.

The recommendation of the OECD Council on regulatory quality and governance, 2012, was adopted on 22 March for all the member states of the OECD and the European Commission. In general terms, the recommendation consists of twelve regulatory principles:

i) political compromise on regulatory quality;

ii) transparency and participation in the regulatory process;

iii) establishing mechanisms to supervise the regulatory policy's proceedings;

iv) integrating the analysis of the regulatory impact from the initial stages of the process;

v) systematic revision of the current regulatory policies, assessing its update, cost justification and consistency;

vi) regular publication of the regulatory policy's performances, including the evaluation of the regulatory impact;

vii) developing a consistent policy which involves the regulatory agencies on the decisions, which shall be objective and impartial, and avoid conflicting interests and improper influences;

viii) ensuring the effectiveness of the revision systems of the legality and procedural impartiality of the regulations;

ix) analysing the effects of the regulation through the risk assessment, risk management and risk communication strategy;

$\mathrm{x}$ ) promoting the regulatory coherence through regulation mechanisms between the different levels: supranational, national and subnational;

xi) fostering the management capacity and the regulatory performance on the subnational levels of the government; 
xii) considering the international standards and cooperation structures on the development of regulatory measures and their effects outside of the respective jurisdiction.

The OECD recommendation is a reinforcement of the previous international initiatives and recommendations of this body on the quality of the law and the analysis of its impact, despite the opinion of the OECD's Secretary General, Angel Gurria, that this Recommendation “... is the first comprehensive document about the regulatory policy since the crisis" (OECD, 2012)".

Prior to 1995, the OECD had recommended the adoption of legislative planning using consultation and its impact evaluation (recommendation of the Council of the OECD on improving the quality of government regulation, 1995) and, soon after, in 1997, it published the evaluation of the legislative impact of the OECD countries as a consequence of the 1995 orientations (Regulatory Impact Analysis - Best Practices in OECD countries, 1997). Since then, the OECD has regularly published the compared performance of its members and of the European Union concerning a set of indicators considered relevant in the pursuit of a "global agenda" supported by the quality and efficiency of the regulatory policy and governance.

In Europe, despite the more temporary regulatory initiatives for legislative simplification, it was in the European Council of Lisbon, in 2000 (Lisbon Strategy, March, 2000) that the legislative quality and efficiency predicated economic development and the nation's prosperity, as well as a more competitive Europe. The outcome of the countries' consultation on primacy of regulatory quality and efficiency was the creation of a working group (Mandelkern group) to conceive the political decisions for better regulation. As a result, the report Mandelkern group on better regulation - final report came out in November 2001, where the regulatory quality and efficacy principles regarding necessity, proportionality, subsidiarity, transparency, responsibility, accessibility and simplicity were profiled. From here, the European Commission's works, in the form of programmes and recommendations for a better regulation, became constant and persevering, over time in the following documents: Better Lawmaking (2002), Better Regulation for Growth and Jobs in the European Union (2005), Smart Regulation (2010a, 2010b), Strategic Review of Better Regulation in the European Union, Better Regulation Agenda (2015), Better Regulation for Better Results (2015), Regulatory Fitness and Performance - REFIT (2016a), among others. The evaluation of the regulation's impact (Integrated Impact Assessment) was made by the EC in 2002, and in 2004, the programme of administrative costs resulting from the law (Standard Cost Model) was established.

\subsection{The Cost and Benefits of the Regulation}

The political initiatives conducting the legislative act entail costs and benefits for the public administration, for the citizens in general, and for the companies in particular. The primacy of the legislative act is that a new regulatory act, in the form of a law, obeys the principles of better efficiency of resources and better regulation efficiency. Regulation efficiency is measured in terms of social, economic and environmental results, that is, better quality of life of the citizens, the competitiveness of the companies and a favourable environment for sustainable growth. 
It is evident that the regulatory act for a certain end or goal has a plethora of options. Any of the options chosen and, therefore, implemented, has a distributive impact, i.e., carries costs and benefits. Now, it is in this sense that international initiatives were executed by the OECD and EC in a joint effort for "better regulation" through the identification and analysis of the costs and benefits of the political initiatives and legislative acts, in an ex-ante and ex-post evaluation of the law.

For the EC, a "better regulation" means a set of rules that ensures that the political decisions are prepared in an open and transparent way, based on the best available evidence and supported by the involvement of concerned parties. A better regulation also means policies and laws that achieve their purposes at a minimum cost (EC, 2015).

In this regard, the legislative act shall obey the evaluation and monitoring before and after its implementation. A rule widespread by the EC (cf. Renda et al., 2013) is that the cycle or process of the legislative act obey an analysis that considers the benchmarks in a "white paper" (white paper on European governance), related to the "green paper" (green paper government report), concerning the purpose of the legislative act, its transposition and implementation, the monitoring and reinforcement, the conformity and the posterior evaluation (impact on society) during a certain period, with regard to assessing the purpose(s) of its conception.

On the EC's political-legal framework, the analysis of a regulatory act obeys a judgement based on the evidence that assess whether each intervention has been (EC, 2015):

- effective and efficient (i.e. the effects correspond to the goals and were achieved at a reasonable cost),

- relevant given the needs and goals,

- coherent with other EC's intervention polices,

- resulting in an accrued value for the EC.

The adopted methodology for the evaluation of the impact of the law by the OECD, Member-States and the EU is called RIA - Regulatory Impact Assessment - or simply IA Impact Assessment. Due to the range and sophistication of RIA in the analysis of the impact of the law, - since its creation, through the development process, including the participation and consultation of the concerned parts, to the completion of the evaluation of its implementation or transposition -, this is the methodology most internationally recommended, despite being poorly applied to the entire cycle of regulatory policies (cf. OECD, 2015). As a reinforcement (or alternative) to RIA, the Standard Cost Model (SCM, EC, 2004) methodology is commonly accepted and adopted by the European Union's Member States to quantify the administrative costs carried by the companies to observe the law. The administrative costs are one of the components of the compliance costs and regulation charges.

\subsubsection{Analysis of the Regulation's Impact: Types of Impact}

The use of the RIA methodology - Regulatory impact assessment - or simply IA - impact assessment - adopted on the EU and OECD's political cycle, either at the creation of a new 
regulation (ex-ante), or to evaluate the current regulation's impact (ex-post), implies a balance between the costs and benefits expected or provoked by the effect of a certain legislative act. Firstly, the main benefit is the reason and/or political goal of that legislative act, as it intends to adjust or alter behaviours that benefit society as a whole or a certain class or segment which was previously underprivileged or unprotected. The common-good principle is subjacent to the public interest and, consequently, to the governmental acts, and in particular, regulatory decisions and policies.

Despite the expectable common-good and public interest that motivate legislative acts (new or renewed), the evaluation of the impact uses a set of variables and indicators to measure the costs-benefits of the regulation. The member countries of the OECD, between 1998 and 2014, integrated a set of economic, social and environmental factors into the regulation's impact evaluation (see e.g. Smith, Erbaci, \& Kauffmann, 2016). Similarly, the European Commission (EC, 2016b) recommends the integration of the following facts within the regulatory impact's analysis: sectorial competitiveness, research and innovation, small and medium-sized enterprises, domestic market, external trade and investment, technology, digital economy and society, fundamental rights and human rights, employment and work conditions, education, culture and youth, health, consumers, territory, country and resources efficiency.

Despite the diversity of the impact factors suitable for integrating the RIA on the analysis of the cost-benefit of the legislative acts and the international recommendations (EU and OECD) on the importance of the regulation's impact on society, economy and environment (the three dimensions of the sustainability evaluation), the member countries of the EU poorly rate the three priority dimensions (Backlund, 2009). Therefore, notwithstanding the international recommendations and governmental initiatives for the regulatory policy, what was expected falls short of what was hoped for. Moreover, the economic-social-environmental regulation's trilogy has been leveraged on the unidimensional perspective of the economic regulatory reform: the evaluation of the regulation's impact on the economic sector (cf. OECD, 2015; WBG, 2016). It is not surprising that the intervention with a bigger impact on "quality of life" and on "inclusive growth" is the economic development of societies, as an enabler of more and better jobs, access to goods and services, and quality of life in general: that is the international desideratum (the OECD and EU) for the nations and mission for 2030. Still, and following this line, the World Bank (WBG, 2015, p.33) defends the notion that "a better regulation is strongly associated with a better perception of the business environment's quality in certain economies".

\subsection{Sustainability and Environmental Regulation}

The international agreements rooted in economic development and progress, on the one hand, and on the fight against climate change, on the other, have placed new challenges for companies: the competitiveness and entrepreneurship in a global political context of environmental restriction. The sustainability factor, as a factor of prosperity of human life, reflects, in a strict sense, the reduction of the waste and resources' efficiency, for the safeguard of the common good as a regulatory principle in the public interest.

The political-legal framework for environmental regulation has restricted the emissions of 
industrial pollutants into the natural environment (air, water and soil), as well as it has regulated the industry in its productive process (Directive 2010/75/EU of 24 November, Decree no. 127/2013 of 30 August). On the preamble of Decree no. 127/2013 (p.5324), the Portuguese Government expresses as a transversal goal to the economic and employment growth that "the current regimes seek to enhance the favourable environment to the investment and sustainable development. In this context, the new legal framework enables the uptake of new investments and creation of new projects for the companies, based on a model with quicker and more transparent proceedings, enables the licensing or authorization on the environment domain and, on the other hand, promotes a greater liability of the economic operators and other entities which intervene on the process". Sustainability gained particular relevance in the international regulatory policies from the 1970s and reflects alternative questions and measures for the social and economic development of the world's population, taking into consideration the new environmental realities and the limited resources. At the core of these initiatives are the pioneer works of the Club of Rome and the international conference of the United Unions in 1972, in Stockholm, known as the "Stockholm's Conference". Since then, the problematic of sustainability earned a global dimension, focused on the protection of the environment.

According to a study of the Massachusetts Institute of Technology (MIT) in collaboration with the Sloan Group (SG), in 2011, sustainability is a key point in the company's economic process and growth. Economic and organisational sustainability and environmental matters are determinant factors such as strategic decisions' weights for the business initiatives concerning sustainability. These factors weigh more on the decisions than corporative social responsibility and employees' or consumers' health and well-being (MITSloan, 2011).

We can conclude that the business initiatives concerning sustainability actions are not a mere aesthetic action to promote brands, strengthen the corporative image and attract clients. A global and liberal market is now piloted by the dissemination of information and technological innovations, together with an international political-legal framework that supports the economy but limits the conditions of goods and services production observing the "environmental patrimony" (physical and natural), as the primacy of the socio-economic sustainability. Companies are faced with a duet of market laws and institutional laws safeguarding both private and public interests. The governments dictate the "ground rules" on behalf of a greater good and the companies compete for their survival and growth. However, the "ground rules" of public interest are also captured by other market participants, the clients. They demand the legality of the "public interest", protection as consumers, the supply and consumption of "green" products, responsible managerial initiatives and business ethics. This is the generalised force that regulates the market mechanisms and leads the companies to more sustainable policies, thereby safeguarding business, investment and legal compliance.

The benefits of environmental regulation are related to sustainability goals, balanced growth, protection of natural resources and biodiversity. In fact, these goals are not limited to the regional and national scale but are rather on a worldwide scale. The social benefits of the environmental impact are measurable in the medium to long term and can be translated into indicators of a better quality of life, through the average lifespan at birth, the decrease in 
episodes of certain diseases and correspondent mortality rates (e.g. respiratory and pulmonary diseases), the reproduction of species, etc. The Portuguese agency of the environment (APA) annually publishes an analysis of the environmental impact, using indicators of air, water and soil quality by the economic sector covered by the legal regime of the environmental impact. The environmental quality can also be consulted on the website of the European Environment Agency $\left(\mathrm{EEA}^{1}\right)$.

On the other hand, the company's costs to comply with the environmental licensing requirements imply an array of direct and indirect financial charges. The costs-benefits equation highlights the idea that the benefits of the environmental licensing are social benefits which are hard to measure, and that the results are hypothetically visible in the medium to long term (Levi-Faur, 2010; Renda et al., 2013; OECD, 2015). The most significant costs are the compliance costs, i.e., the costs of the administrative activities for the observance of the law, by the citizen and/or company. A large proportion of the activities incurred by the companies to observe the mandatory information and, therefore, arising from the law, are translated into the compliance activities of the information obligation/duties towards the formal regulation agency and other public entities which intervene in the regulation and monitoring of the observance of the law. Now, one of the central aspects of the "better regulation" (EC, 2015) is to reduce the company's administrative charges. The European Union estimated that the impact of a $25 \%$ reduction of the administrative costs would save 150 billion euros. The projection of this reduction percentage to 2025 would be $1.3 \%$ of the GDP for Europe and 1.7\% of the GDP for Portugal (EC, 2006).

The reduction of the administrative charges and the simplification of the regulation has been one of the priorities included on the European Commission's work programme for the last few years. For 2018, the Commission's work programme adds 17 new initiatives of simplification and reduction of the administrative charges. From these initiatives, the first priority is the environmental scope (EC, 2017a, 2017b). Alongside this, a study of Torriti \& Ike (2014), which analysed the impact of the initiatives of administrative costs' reduction for the companies of 32 developed countries, concluded that, in the majority of the countries, these initiatives increased foreign investment, and that the benefits are greater in those countries that apply the Standard Cost Model (SCM) methodology for a longer period.

To reduce the administrative charges arising from regulation it becomes necessary to identify and quantify those charges. The measurement is the tool for their reduction. It is with this purpose that we continue with the case study presented below.

\section{Case Study: The Impact of the Environmental Law on Administrative Costs of Portuguese Poultry}

\subsection{Context and Relevance of the Study}

The adoption of the case study method is of particular interest in the research and analysis of a restricted context (Creswell, 1994) which is not generally known. This method studies a

\footnotetext{
${ }^{1}$ Information and data available at http://www.eea.europa.eu/
} 
phenomenon in its particular context (Yin, 1994) and uses data gathered from various sources. This type of method traditionally assumes a qualitative modality of data analysis, even though a mixed approach (qualitative and quantitative) allows a better understanding of the "case" which is to be studied.

This study uses various information sources and a mixed methodology for the analysis and interpretation of the results. The first stage is the analysis and interpretation of specific legislation and other related documents. This leads to a questionnaire of closed questions which target statistically handled companies.

\subsection{Object of Study and Measurement Instrument}

This work aims to determine the administrative costs to the companies within the poultry sector arising from the Decree no. 127/2013 of August 30" , which "establishes the regime of industrial emissions applicable to the integrated pollution prevention and control, as well as the rules which seek to avoid and/or reduce the emissions to the air, water and soil and the production of residues, to achieve a high level of environmental protection as a whole (...)" (art. 1, Decree no. 127/2013).

The Decree no. 127/2013, known as "environmental license" (EL), was recorded as the Portuguese Directive no. 2010/75/EU of the European Parliament and Council, of November $24^{\text {th }}$, 2010, concerning the industrial emissions, which results from the Decision no. 1600/2002/EC of the European Parliament and the Council of June 22 nd 2002 , which established the sixth Community action program on environmental matters. The environmental license (EL) forms part of the license of exploitation (LE) of facilities and covers the facilities mentioned in the Annex I of the Diploma (Decree no. 127/2013) where all the necessary measures for the defence and protection of the air, water and soil, for the reduction of sound pollution and for the production of residues are included. The environmental license also considers, for decisive effects of licensing of an activity present in the correspondent Diploma, the best available techniques (BAT) for the covered sector of activity $^{2}$, despite the fact that the EL can only include a reference to the binding rules (art. 8, no. 1).

The EL covers (Annex I, Decree no. 127/2013):

- Industry of the energetic sector

- Production and transformation of metals

- Mineral industry

- Waste management

${ }^{2}$ The best available techniques (BAT) are benchmarks approved by an international committee and available at http://eipps.jrc.ec.europa.eu/reference. The environmental licensing implies, from the operators covered by the activities and conditions of the Annex I of the Decree no. 127/2003, general binding rules that are substantiated by the BAT (art. 8, no. 2). 
- Other industrial and farming activities.

The entity responsible for the EL emission is the Portuguese Environment Agency (APA, I.P). APA is a Public Institute ${ }^{3}$ integrated with the indirect State administration and overseen by the Ministry of Agriculture, Sea, Environment and Land-Use Planning.

Within the economic activity sectors covered by the mentioned Diploma, the poultry sector was our choice (point 6.6a) of Annex I.

To measure the administrative costs for the Portuguese poultry companies, the O Guia Prático para a quantificação dos encargos administrativos de acordo com a metodologia Standard Cost Model - Manual PT SCM (The Practical Guide for the quantification of administrative burdens according to SCM methodology) was applied, published by the Administrative Modernization Agency (AMA). This is a Portuguese version and adaptation of the Standard Cost Model - a framework for defining and quantifying administrative burdens for business (Standard Cost Model Network, EC, 2004).

The AMA, I.P. is a Public Institute overseen by the Deputy State Department of the Presidency of the Council of Ministers, with functions clarified through administrative modernization and simplification, and through electronic administration areas.

The International SCM, as mentioned before, is the methodology adopted by the European Commission and its Member-States to identify and quantify the administrative charges arising from the observance of the law, by the citizens and, particularly, by the companies. SCM can be used on an ex-ante analysis, that is, as a preventive and prognostic way to evaluate the administrative costs of a new law and it can be used on an ex-post analysis to measure the factual administrative consequences arising from the implementation (and/or transposition) of the law. The version PT SCM (AMA) focuses on the ex-post evaluation.

The analysis of administrative charges, through the SCM, focuses on the administrative compliance costs and is one of the components of the total regulation's costs (see Fig. 1).

\footnotetext{
${ }^{3}$ The duties and mission of APA, I.P. are defined by the Decree no. 56/2012 of March $12^{\text {th }}$, and its internal organization (statutes) is defined by the Decree no. 108/2013 of March $15^{\text {th }}$.
} 


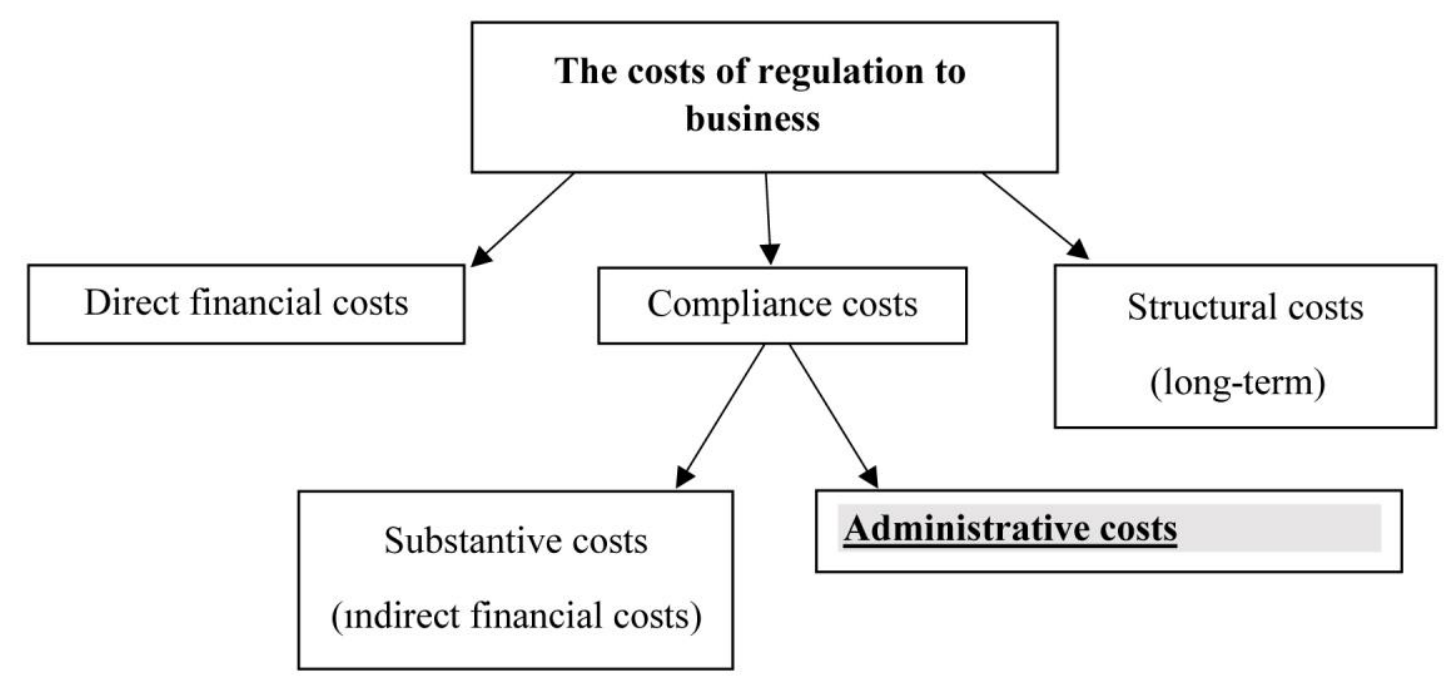

Figure 1. Costs of regulation to business.

Source: SCM Network.

With Fig. 1 in mind, and using the Decree no. 127/2013, the direct financial costs include the rates that the operators pay to the public authorities (regulatory authority, competent authority for the preparatory instruction of the process) by virtue of the licensing request, and also the fines arising from the non-observance of the rules legally established for the exercise of the activity. The long-term structural costs are difficult to calculate, as they are variable costs for a period longer than a year. During this period, the companies use their knowledge to compare and combine different ways of production and processes technologies. The costs arising from the obligation to adopt the best available techniques (BAT) and other techniques to ensure the limit values of emission (LVE) can, in the long-term, mitigate or even cancel the costs of its adoption, through the company's performance improvement. The substantive or indirect financing costs are the costs associated with legal bonds that imply the acquisition and alteration of the process or the product, for example, the observation of environmental requirements such as the acquisition of filters. Finally, the administrative costs highlight the administrative or bureaucratic process that leads to the observance of the information obligations (i.e., mandatory provision of information). The SCM focuses on this last regulatory cost: the administrative costs.

Methodologically, SCM PT registers the reporting obligations taken from the law (event), and to each of these obligations splits the necessary information elements (or required data). Later, the administrative activities necessary to fulfil the information elements arising from each of the obligations are identified. For each activity, the costs are calculated, through the parameters of spent time and fare prices.

In detail, the information obligations are the obligations that arise from the law concerning the provision of information or data to the public sector and/or third parties. The information elements are registered and divided according to each information obligation identified by the law, and include all necessary data and information required by each obligation. The 
administrative activities or actions performed by the operator are detailed according to each of the information elements. The activities can be internal or external. For example, the need to contract specialized services is called "other charges" and it is associated with the performance of activities according to the information obligations.

Therefore, the cost per activity results from the application of the following formula:

Cost per administrative activity $=$ tariff $\mathrm{x}$ time $\mathrm{x}$ quantity (population $\mathrm{x}$ frequency)

where:

the tariff is the cost-hour to perform the activity;

the time refers to time units (e.g. minutes or hours) necessary to perform the activity;

and the quantity represents the number of times an activity has to be performed per year (frequency), and the number of companies covered by that event (population).

Fig. 2 clarifies the methodology division.

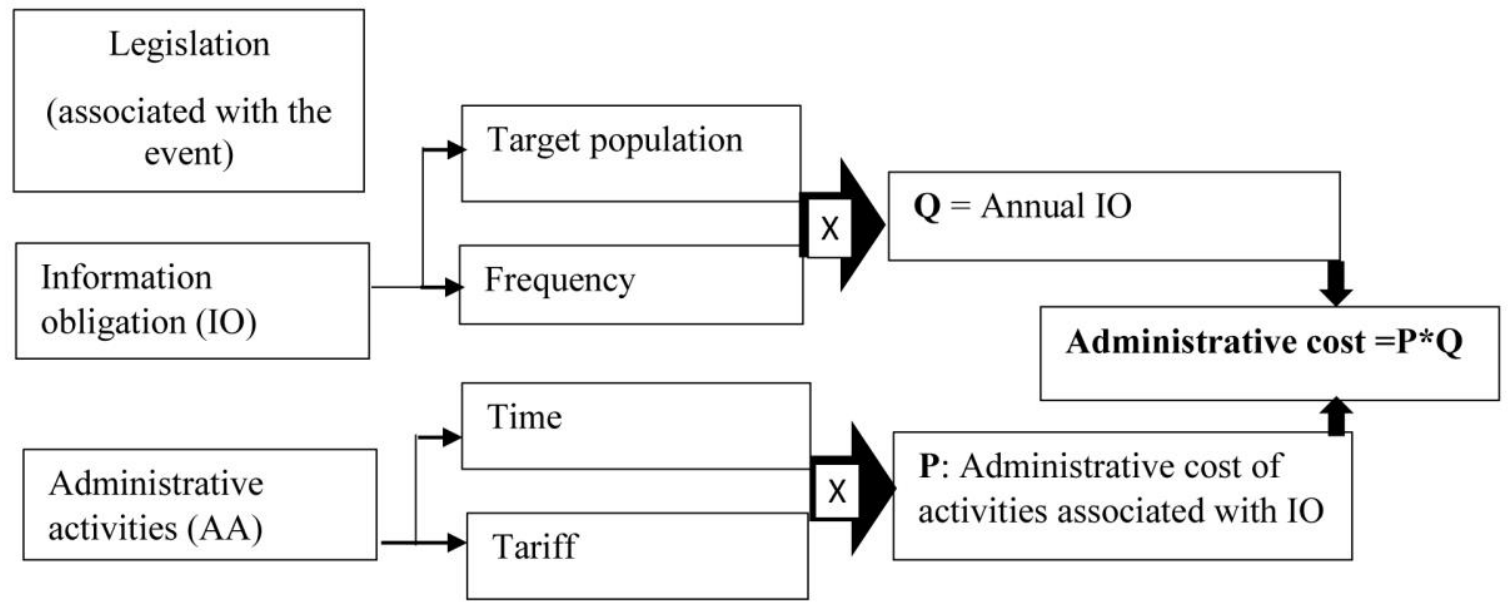

Administrative costs $I_{0}=\sum_{A A}($ time $X$ tariff + others costs $) X($ population $X$ frequency $)=$ Price ol X Quantity (total IO delivery per year)

Figure 2. Determination of administrative cost

Source: Manual PT SCM, AMA

The PT SCMA recommends the following steps for the analysis of each law (or event):

$1^{\text {st }}$ step - From the law, extract the information obligation (IO) and the information elements (IE).

$2^{\text {nd }}$ step - Inventory of administrative activities (AA) necessary to fulfil all the information elements to each of the information obligations identified.

$3^{\text {rd }}$ step - Select the economic operators and proceed to the application of the instrument 
(questionnaire) arising from the $1^{\text {st }}$ and $2^{\text {nd }}$ steps.

With regard to this step, we recommend the rationalization of the number of segments to consider for the analysis, "since that the greater the number of segments, the greater the effort and difficulty in its characterization (in terms of cost, population, frequency, etc.)" (PT SCM, AMA, p.19).

After the definition of the segment, a sample of companies is chosen. The sample shall contain 5 observations to each reporting obligation and shall comprise companies of medium efficiency (idem, p. 27).

The quantification of the time corresponds to the time spent to perform each of the administrative activities (AA) on the mandatory provision of information.

$4^{\text {th }}$ step - Calculate the standard cost of the economic sector.

The standard cost of the sector or segment results from the average (or median, in cases of great value variability found on the observations) of the spent times for each of the sampling operators, multiplied by the "intervenient profile", that is, the cost per hour or minute of the employee's salary.

$5^{\text {th }}$ step - Extrapolate for the population

The extrapolation for a target population is done with reference to the standard operator $\left(4^{\text {th }}\right.$ step) and multiplied by the economic operations of that sector or economic activity and covered by the same diploma (i.e., by the same information obligations).

The frequency is the number of times an operator fulfils the information obligation. In the case that it is not possible to define a frequency, the number of occurrences shall be considered, that is, the real fulfilment rate.

Thus, the Quantity = target population $\mathrm{x}$ frequency (or occurrences)

\subsection{Sample}

For the application of the PT CSM methodology to the Decree no. 127/2013 of August $30^{\text {th }}$ that, as previously mentioned, regulates the exercise of certain economic activities prone to environmental pollution (described in Annex I of the Diploma), the poultry activity was our choice (point 6.6 "instalment for the intensive raising of poultry and pigs with more than", paragraph a): 40.000 places for poultry).

The sample follows the criteria defined on the PT SCM and comprises 5 poultry companies. The companies were firstly selected through the consultation of the official page (on-line) of the Portuguese Environment Agency (APA). The companies with the environmental license (EL) approved were registered. Consequently, they were contacted, via telephone or email. In certain cases, face-to-face contact occurred.

For the purpose of this work, the selected economic activity has relative importance and focuses on the clearance of the administrative costs induce of the industrial emissions regime. That is, despite the specifications of the allowed emissions for the air, soil and earth for each 
of the sector and/or activity covered by the Diploma, this is transversal to all the activities covered by the same legal information obligations.

Briefly, poultry fits within the farming sector and is characterized by the production of poultry meat (mainly chickens and hens) and eggs. At the end of 2015, the Portuguese poultry sector earned nine hundred million euros, with a gross production of three hundred and forty thousand tons of meat, employed more than two hundred thousand people, was responsible for $10 \%$ of the gross agricultural product (GAP) and was the tenth biggest producer in Europe. Portugal is also the biggest consumer of poultry meat in the European Community: $37,5 \mathrm{~kg}$ per capita compared to the average in the European Union of 22,5 $\mathrm{kg}$ per capita (INE, 2016). With regard to the production of eggs, the annual national production is more than one million five hundred thousand eggs and the consumption per capita is one hundred and seventy-five eggs per year (INE, 2018). The development and growth of the poultry sector stimulates other economic activities of agriculture, industry and trade. For example, the production of cereals, namely corn, where poultry is the biggest consumer, but also the production of compound feeds (animal feeds) and the trade of veterinary medicines.

\subsection{Results}

The presentation of the results follows the methodological logic of the SCM using their required measurement instrument.

$I^{\text {st }}$ step - From the law - Decree no. $127 / 2013$ of August $30^{\text {th }}$ - extract the information obligations (Ro) and the information elements

\subsubsection{Information Obligations (IO)}

From the reading of the Decree no. 127/2013 of August $30^{\text {th }}$, the following information obligations were extracted:

- Information Obligation 1 (IO 1): License of Exploitation / Environmental License - art. 11 art.11 - Issuance of a license

" 1 - The issuance of licenses pursuant to this decree is a previous mandatory condition to the exploitation of the facility.

2 - The title of exploitation of a facility issued by the Coordinating Entity (EC) is preceded from the approval of the EL request or its tacit approval."

- Information Obligation 2 (IO2 2): Re-evaluation of the Environmental License (encompassed here: alteration of the facility - art. 19, transmission of licenses - art. 20 and license renewal - art. 21)

art. 19 "are considered alterations of exploitation for the EL effects:

a) The alteration of the characteristics, functioning or expansion of the facility which can have consequences for the environment, namely the ones which induce a relevant effect on the conditions specifically established on the issued EL;

b) The substantial alteration of the activities performed on a facility which correspond to the limits established in annex I; 
c) The transmission, at any title, of the exploitation or characteristic of a part of the facility, subject to one EL;

d) Update of the EL resulting from the provisions in no. 7."

art. 20 "transmission of licenses

1- The licenses may be transmitted through request of the submitter or the assignee sent to the EC, presented on the APA, I.P., after confirmation of the endorsement to the process (...)."

art. 21 "License renewal

1- The operator sends to APA, I.P, through the EC, to the maximum of six months before the term of the period of validity established on the corresponding license, the elements that guided the licensing request that lack an update, when striving for the license renewal. (...)"

- Information Obligation 3 (IO 3) - Accidents, incidents and non-compliance- art. 9 e art. 10 art. 9 "Accidents and incidents

Without prejudice of the provisions of the legal regime of liability for environmental damage (...), if any accident or incident occurs that significantly affects the environment, the operator should:

a) Immediately execute the measures deemed adequate to limit the consequences to the environment (...);

b) Inform APA, I.P., at the latest 48 hours (...);

c) Execute the complementary measures that APA, I.P considers necessary to limit the consequences for the environment and avoid new accidents or incidents."

art. 10 "Non-compliance of the licenses conditions

Whenever the non-compliance of some of the license conditions pursuant to this decree is verified, the operator should:

a) Inform EC and APA, I.P., or the territorially competent CCDR (Regional Coordination and Development Commission) (...);

b) Immediately execute the necessary measures to restore the license conditions as soon as possible;

c) Execute the complementary measures that the authorities mentioned on paragraph a) deem necessary to re-establish the compliance."

\subsubsection{Information Elements (IE)}

For each of the information obligations above-mentioned (IO 1, IO 2 and IO 3), drawn from the Decree no. 127/2013, we now perform the extraction of the necessary elements to the compliance of each of the information obligations:

Information elements (IE) for the compliance of the information obligations: License of 
Exploitation / Environmental License (IO 1):

IE 1 - Base report for the licensing request - art. 35 - Request of environmental license

The following are information elements for the fulfilment of the base report:

1.1 Identification of the raw materials;

1.2 Identification of the emission sources;

1.3 Pieces designed on a digital support;

1.4 Description of the planned technologies and other techniques;

1.5 Description of the prevention, valuation and compliance measures;

1.6 Description of the measures planned for the monitoring of the emissions to the environment;

1.7 Data for usage of the hydric resources;

1.8 Data concerning the fate of effluents;

1.9 Data concerning the fate of animal cadavers;

1.10 Non-technical summary of the previous elements;

1.11 Registry/Alteration of the environmental technician

Information elements for the information obligation: License Re-evaluation (IO 2):

To repeat the same information elements of IO 1.

Information elements for the information obligation: Occurrence of accidents/incidents and non-compliance (IO 3):

To repeat the same information elements of IO 1 and IO 2, except the information element 1.11 - Alteration of the environmental technician.

$2^{\text {nd }}$ step - Inventory the administrative activities $(A A)$ necessary to fulfil all the information elements for each of the information obligations identified (IO 1 to IO 3).

SCM recommends that the inventory of the administrative activities necessary to fulfil the legal obligations and the correspondent information elements is done.

In practice, the obligations and the information element should cross the administrative activities with the purpose of calculating, a posteriori, the times and correspondent costs of all the obligatory information elements, through the calculation of each of the necessary administrative activities (time $\mathrm{x}$ operation cost) and the sum of all the activities for each of the information elements. The total of the administrative activities (time and cost) for each of the information elements (IE) of an information obligation (IO) will result in the charges of the economic operator to fulfil that certain law obligation (e.g. Environmental Licensing).

In this regard, all the administrative activities possible and plausible in considering the 
information elements were inventoried. Thereafter, the administrative activities were identified and described.

\subsubsection{Identification and Description of the Administrative Activities (AA)}

1. Familiarization - time dedicated to the full knowledge of the law formalities and the actions to fulfil these formalities.

2. Gathering of information - time spent on the gathering of the necessary information to execute the formalities.

3. Meetings - time spent on internal meetings and meetings with specialists to organize and "manage" the actions that lead to the fulfilment of the formalities.

4. Filling of forms - time dedicated to the filling of the forms, questionnaires and other documents of mandatory origin, on paper or electronically, to fulfil the formalities.

5. Storage of information - time necessary to storage the information (when it is a required formality).

6. Prints/ copies - time spent on prints and copies of documents necessary to fulfil the formalities.

7. Travels - time spent on travelling (short or long) to other services, when necessary, to observe the formalities.

8. Waiting time - time elapsed from the arrival of request to the service or approval of the requested and mandatory information to fulfil the formalities.

9. Data adjustment - time spent to update, correct or reformulate data or other information that were re-evaluated by an external entity and that is a formality for the observance of law. 10. Inspection/ internal monitoring - time spent per internal personnel to the company (employee) on the inspection, monitoring or auditory in the scope of the legal obligations observance.

11. Inspection/ external monitoring - time spent per employee of a company on the reception and guidance of inspectors, auditors and/or technicians (external to the company) which, within the scope of its duties, are fulfilling legal obligations.

12. Reports - time spent on the preparation of reports that are mandatory to the fulfilment of formalities.

13. Incidents registry - time spent on the recording and correction of situations/conditions considered "abnormal" which are provoked by incidents and/or accidents, aiming the functioning or the legally "acceptable" fulfilling.

Other costs

14. Other unforeseen rates - charges (monetary cost or currency unit) in the acquisition of external services and equipment to realize the law demands (for example, the exact hiring value of an external service (consulting) or of a specialized technician for a short period of 
time, and/or the acquisition of informatics equipment necessary to fulfil the legal demands, or cabinets or other property support to storage the information).

$3^{\text {rd }}$ step - Select the economic operators and proceed to the application of the instrument (questionnaire) arising from the $1^{\text {st }}$ and $2^{\text {nd }}$ steps.

The PT SCM Manual recommends the segmentation per event and that the sample selection focus on the most representative companies of the segment, i.e., "standard" companies of medium efficiency. It recommends 5 observations for each information obligation.

We should state that the conception of the SCM methodology focuses on the goals of simplification and reduction of the administrative charges, deriving from the law. In this regard, for a certain event (e.g. set of legal obligations extracted from a law), all the companies of the segment (i.e., activity sector or sectors covered by that law) are bound by the legal compliance to the information obligations in that same law, through the provision of a set of elements and/or actions. This way, it is assumed that the sample based on the assumption of "standard companies" shall reveal a "standard" of the administrative cost's performances for the covered companies. The SCM's application does not require statistic representation.

Therefore, after establishing contact with several referred companies of poultry production, it was possible to apply the questionnaire to a set of 5 companies with the structure of a medium business (from 50 to 240 employees).

Before the application of the questionnaire, there were many calls, information and clarifications provided via email and on-site presence, for some cases.

To each company, it was possible to register the time, spent per employee, for the performance of the administrative activities which led to the fulfilment of each of the legal obligations.

The profile of the "type" employee, the one who performs administrative activities necessary to the fulfilment of each information obligation (IO1 to IO3), was also registered.

The "employee profile" is defined by INE and follows a scale of 1 to 3: 1 - management position; 2 - technician or specialized collaborator; 3 - administrative or worker.

This indicator is relevant for the calculation of the administrative costs:

Tariff $\mathrm{x}$ time $=$ administrative cost of the activities

To gather the information on the salaries of different employee profiles, the report "income and work duration" drawn by the Office for Strategy and Planning of the Ministry of Work, Solidarity and Social Security, with data reported on 2016, was utilised.

Thus, the adjustment to the terminology used for the different working classes was made, the monthly remunerations were extracted and the cost of work per hour and minute was calculated (consult table 3). 
Table 1. Professional Profiles and salaries.

Basic remuneration (€) of the Portuguese professional profiles: 2016

\begin{tabular}{l|l|c|c|c|c}
\hline \multicolumn{2}{c|}{ Professional Profiles } & Monthly & $\begin{array}{c}\text { Day } \\
(\mathbf{2 2} \text { days })\end{array}$ & $\begin{array}{c}\text { Hours } \\
(\mathbf{8 h} / \text { day })\end{array}$ & Minutes \\
\hline Profile 1 & Executives & $2.169,40$ & 98,64 & 12,32 & 0,21 \\
\hline Profile 2 & $\begin{array}{l}\text { Employee } \\
\text { (technical or } \\
\text { specialist) }\end{array}$ & $1.006,59$ & 45,77 & 5,72 & 0,10 \\
\hline Profile 3 & $\begin{array}{l}\text { Worker (or } \\
\text { administrative) }\end{array}$ & 699,73 & 31,81 & 3,98 & 0,07 \\
\hline
\end{tabular}

Source: Adapted from GEP-MTSSS (2017).

\section{$4^{\text {th }}$ step-Calculate the standard cost of the economic sector}

SCM - PT recommends that the calculation of the administrative cost representative of the sector, that is, the calculation of the "standard company" of the sector, shall be determined via the statistic median of each one of the registered administrative activities for each company, therefore preventing that exceptional values distort the analysis.

Particularly, in our case, the registry of the minutes spent on each of the activities necessary to the obligations fulfilment, for each of the companies of the sample, was based on an almost inelastic temporal behaviour and, for this reason, we proceeded to the assessment of the "standard company" using the statistic median.

The times were registered on minutes spent by the employee to execute each of the administrative activities (AA). The determination of the cost per time unit (minutes) was calculated through the average of "profile 1" - executives - and "profile 2" - technical or specialist employee - which corresponds to 0,16 cents/minute of work. The employees that performed the administrative activities which led to the fulfilment of legal obligations were, in some cases, executives and, in other cases, environmental technicians/specialists. In two of the cases, both situations were included.

Tables 2 and 3 can be consulted for the "standard company" results. In Table 2, we present the results of the times spent to perform the administrative activities (from 1 to 14) and in Table 3 , the administrative costs charged for the time spent on those same activities. Additionally, those tables report "other costs". These "other costs" cannot be considered mere administrative costs, but costs that derive from the fulfilment of administrative activities.

\section{$5^{\text {th }}$ step - Extrapolate results for the population}

The last step is to extrapolate the results of the "standard company" for the population. In this step, it was necessary to obtain data concerning the covered population (number of companies of the sector or covered by a certain economic activity), the frequencies and/or occurrences (number of times necessary to report the information). The quantities are annual, by definition of the SCM. 


\section{Macrothink}

Journal of Public Administration and Governance ISSN 2161-7104 2018, Vol. 8, No. 3

The frequencies are, mainly, determined by the law. For example, the environmental license is valid for 10 years, and the inspections shall precede the formalization of the environmental license as an administrative act. The population values and other concerning "occurrences" were provided by the Portuguese Environment Agency (APA).

The extrapolation of times and cost/time for the Portuguese poultry's population can be seen in Tables 4 and 5, respectively. 


\begin{tabular}{|c|c|c|c|c|c|c|c|c|c|c|c|c|c|c|c|}
\hline & & & Ins & on of & & $g$ of & $y(\mathrm{An}$ & I - 6.6. & 10000 & es for & ltry) & & & & \\
\hline \multicolumn{16}{|c|}{ IO 1 - Exploitation Licence (ExL) and Environmental Licence (EL): } \\
\hline \multicolumn{16}{|c|}{ Administrative Activities (TIME for the STANDARD COMPANY : minutes) - SCT } \\
\hline $\begin{array}{l}\text { IE (Information } \\
\text { Elements): }\end{array}$ & 竧 & 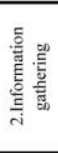 & $\sum_{n=0}^{\infty}$ & 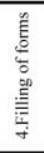 & 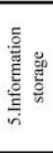 & 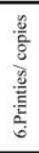 & 觉 & 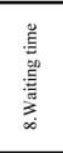 & 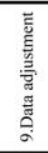 & 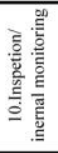 & 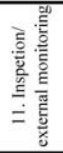 & 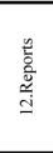 & 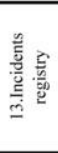 & 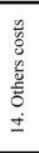 & 㺼 \\
\hline $\begin{array}{l}\text { Base report for the } \\
\text { license request }\end{array}$ & 480 & 240 & 60 & 60 & 10 & 30 & 0 & 19.200 & 960 & 240 & 120 & 960 & 60 & 0 & 22.420 \\
\hline $\begin{array}{l}\text { Description of the } \\
\text { installation and the } \\
\text { activities and conditions }\end{array}$ & 2.400 & 1.200 & 960 & 60 & 10 & 30 & 60 & 0 & 480 & 120 & 45 & 240 & 30 & 0 & 5.635 \\
\hline $\begin{array}{l}\text { Identification of raw } \\
\text { materials }\left(\mathrm{H}_{2} \mathrm{O}\right)\end{array}$ & 480 & 240 & 60 & 60 & 10 & 15 & 0 & 0 & 60 & 60 & 30 & 240 & 30 & 0 & 1.285 \\
\hline $\begin{array}{l}\text { Identification of the } \\
\text { emission source }\end{array}$ & 960 & 240 & 60 & 60 & 10 & 15 & 0 & 0 & 60 & 60 & 45 & 240 & 30 & 0 & 1.780 \\
\hline $\begin{array}{l}\text { Pieces designed on a } \\
\text { digital support }\end{array}$ & 2.400 & 1.440 & 960 & 30 & 10 & 60 & 0 & 0 & 60 & 480 & 45 & 240 & 30 & 0 & 5.755 \\
\hline \begin{tabular}{|l} 
Description of the \\
techonologies planned \\
and other techniques
\end{tabular} & 960 & 480 & 30 & 60 & 10 & 15 & 0 & 0 & 60 & 120 & 30 & 240 & 30 & 0 & 2.035 \\
\hline \begin{tabular}{|l|} 
Description of the \\
prevention, valuation and \\
compliance measures
\end{tabular} & 1.440 & 240 & 30 & 60 & 10 & 15 & 0 & 0 & 60 & 120 & 45 & 120 & 30 & 0 & 2.170 \\
\hline \begin{tabular}{|l|} 
Description of the \\
measures planned for the \\
monitoring of the \\
emissions to the \\
environment
\end{tabular} & 960 & 480 & 60 & 60 & 10 & 15 & 0 & 0 & 60 & 120 & 45 & 120 & 30 & 0 & 1.960 \\
\hline $\begin{array}{l}\text { Data for usage of hydric } \\
\text { resources }\end{array}$ & 480 & 120 & 30 & 30 & 10 & 15 & 0 & 0 & 60 & 30 & 45 & 240 & 30 & 0 & 1.090 \\
\hline $\begin{array}{l}\text { Data concerning the fate } \\
\text { of effluents }\end{array}$ & 240 & 60 & 15 & 15 & 10 & 15 & 0 & 0 & 30 & 30 & 45 & 60 & 30 & 0 & 550 \\
\hline $\begin{array}{l}\text { Data concerning the fate } \\
\text { of animals cadavers }\end{array}$ & 240 & 60 & 15 & 15 & 10 & 15 & 0 & 0 & 30 & 30 & 45 & 60 & 30 & 0 & 550 \\
\hline $\begin{array}{l}\text { Non-technical summary } \\
\text { of the previous elements }\end{array}$ & 2.400 & 960 & 120 & 60 & 10 & 15 & 0 & 0 & 120 & 30 & 45 & 240 & 30 & 0 & 4.030 \\
\hline \begin{tabular}{|l|} 
Registry of the \\
environmental technician
\end{tabular} & 4.800 & 2.400 & 480 & 120 & 60 & 60 & 0 & 0 & 240 & 480 & 60 & 240 & 60 & 0 & 9.000 \\
\hline TOTAL & 18.240 & 8.160 & 2.880 & 690 & 180 & 315 & 60 & 19.200 & 2.280 & 1.920 & 645 & 3.240 & 450 & 0 & 58.260 \\
\hline
\end{tabular}

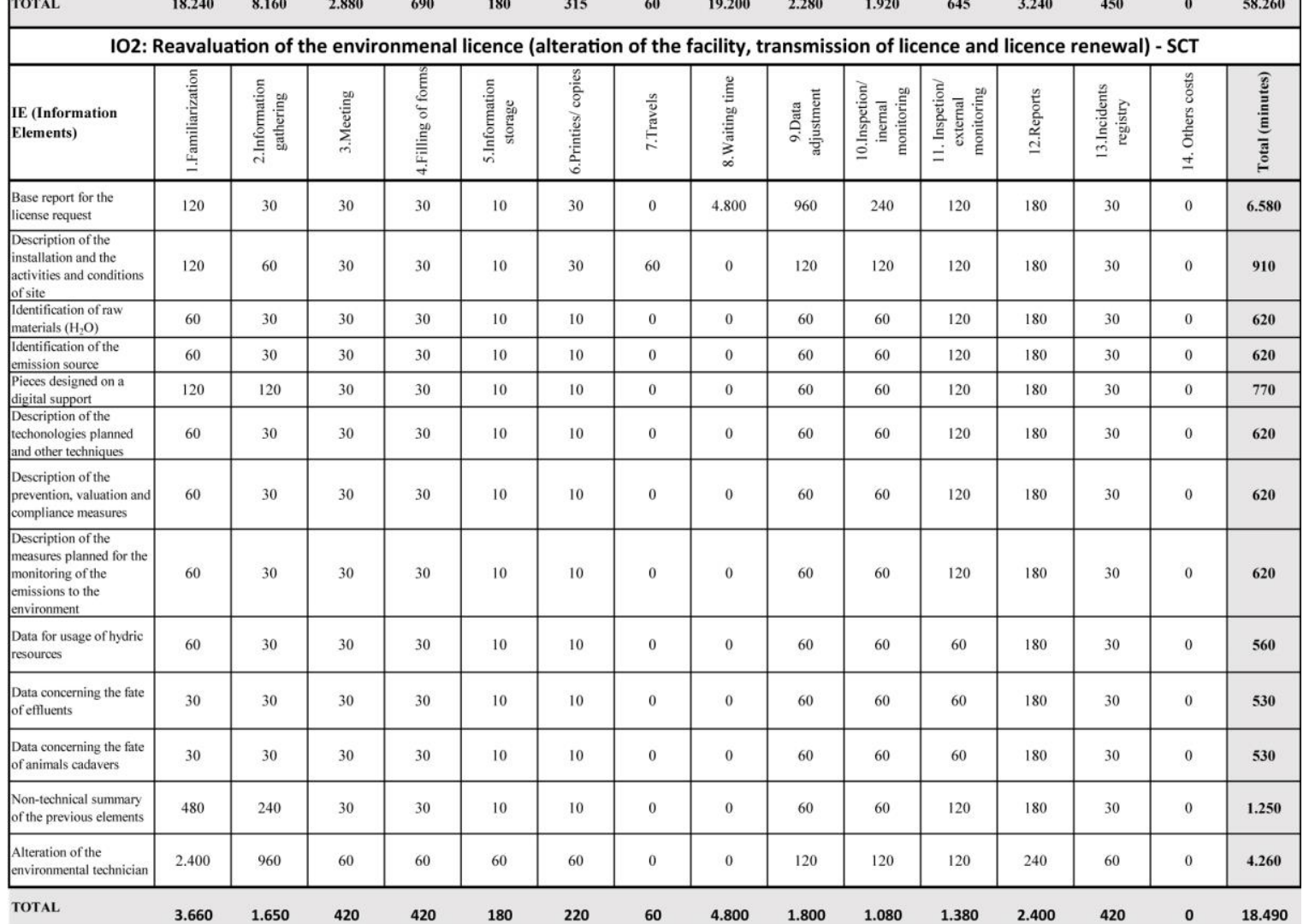


Table 2: Time to Standard Company - Cont.

\begin{tabular}{|c|c|c|c|c|c|c|c|c|c|c|c|c|c|c|c|}
\hline & & 103: A & cidents & nciden & and no & omplia & e (su & ey carri & out by & regulato & $y$ agenc & - SCT & & & \\
\hline $\begin{array}{l}\text { Ei (Elementos de } \\
\text { informação) }\end{array}$ & 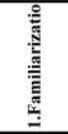 & 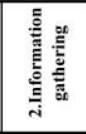 & 竞 & 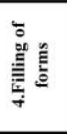 & 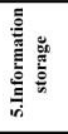 & 产 & 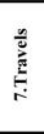 & 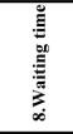 & 吾 & 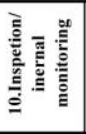 & 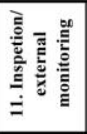 & 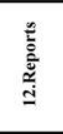 & 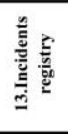 & 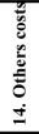 & 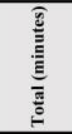 \\
\hline $\begin{array}{l}\text { Base report for the } \\
\text { license request }\end{array}$ & 120 & 30 & 30 & 15 & 10 & 30 & 0 & 960 & 480 & 120 & 120 & 120 & 60 & 0 & 2.095 \\
\hline \begin{tabular}{|l|}
$\begin{array}{l}\text { Description of the } \\
\text { installation and the } \\
\text { activities and conditions } \\
\text { of site }\end{array}$ \\
\end{tabular} & 60 & 60 & 30 & 15 & 10 & 30 & 30 & 0 & 60 & 60 & 120 & 30 & 30 & 0 & 535 \\
\hline \begin{tabular}{|l|} 
Identification of raw \\
materials (ḤO)
\end{tabular} & 30 & 30 & 30 & 15 & 10 & 10 & 0 & 0 & 30 & 60 & 120 & 30 & 30 & 0 & 395 \\
\hline $\begin{array}{l}\text { Identification of the } \\
\text { emission source }\end{array}$ & 30 & 30 & 30 & 15 & 10 & 10 & 0 & 0 & 30 & 60 & 120 & 30 & 30 & 0 & 395 \\
\hline $\begin{array}{l}\text { Pieces designed on a } \\
\text { digital support }\end{array}$ & 180 & 60 & 30 & 15 & 10 & 10 & 0 & 0 & 30 & 60 & 120 & 30 & 30 & 0 & 575 \\
\hline \begin{tabular}{|l} 
Description of the \\
techonologies planned \\
and other techniques \\
\end{tabular} & 30 & 30 & 30 & 15 & 10 & 10 & 0 & 0 & 30 & 60 & 120 & 30 & 30 & 0 & 395 \\
\hline $\begin{array}{l}\text { Data for usage of hydric } \\
\text { resources }\end{array}$ & 120 & 30 & 30 & 15 & 10 & 10 & 0 & 0 & 30 & 60 & 120 & 30 & 30 & 0 & 485 \\
\hline $\begin{array}{l}\text { Data concerning the fatt } \\
\text { of effluents }\end{array}$ & 30 & 30 & 30 & 15 & 10 & 10 & 0 & 0 & 30 & 30 & 120 & 30 & 30 & 0 & 365 \\
\hline $\begin{array}{l}\text { Data concerning the fatt } \\
\text { of animals cadavers }\end{array}$ & 30 & 30 & 30 & 15 & 10 & 10 & 0 & 0 & 30 & 30 & 120 & 30 & 30 & 0 & 365 \\
\hline $\begin{array}{l}\text { Non-technical summary } \\
\text { of the previous elements }\end{array}$ & 30 & 30 & 30 & 30 & 30 & 30 & 0 & 0 & 30 & 30 & 120 & 30 & 30 & 0 & 420 \\
\hline TOTAL & 840 & 420 & 360 & 195 & 140 & 180 & 30 & 960 & 840 & 690 & 1.440 & 450 & 390 & 0 & 6.935 \\
\hline
\end{tabular}


Table 3: Administrative Cost for standard company

\begin{tabular}{|c|c|c|c|c|c|c|c|c|c|c|c|c|c|c|c|}
\hline \multicolumn{16}{|c|}{$\begin{array}{l}\text { Decree No. 127/2013 of August 30th, } 2013 \text { (transposing the Directive 2010/75/EU of the Parliament and the Council of November 24th, 2010) } \\
\text { Instalation of intensive raising of poultry (Annex I - 6.6. a) } 40000 \text { places for poultry }\end{array}$} \\
\hline \multicolumn{16}{|c|}{$\begin{array}{l}\text { IO1: Exploitation Licence (ExL) and Environmenatl Licence (EL): } \\
\end{array}$} \\
\hline \multicolumn{16}{|c|}{ Administrative Activities (cost for standard company -CSC) } \\
\hline $\begin{array}{l}\text { IE (Information } \\
\text { Elements): }\end{array}$ & 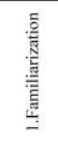 & 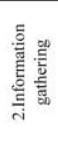 & $\sum_{m}^{\infty}$ & 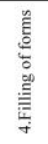 & 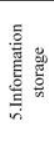 & 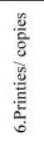 & 党 & 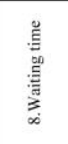 & 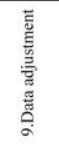 & 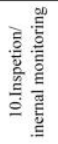 & 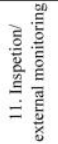 & 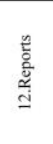 & 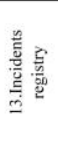 & 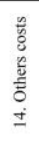 & ฮू̆ \\
\hline $\begin{array}{l}\text { Base report for the } \\
\text { license request }\end{array}$ & $77 \epsilon$ & $38 €$ & $10 €$ & $10 €$ & $2 \epsilon$ & $5 €$ & $0 €$ & $3.072 \epsilon$ & $154 \epsilon$ & $38 €$ & $19 €$ & $154 €$ & $10 €$ & $0 €$ & $3.587 €$ \\
\hline \begin{tabular}{l|} 
Description of the \\
installation and the \\
activities and conditions \\
of site
\end{tabular} & $384 \epsilon$ & $192 \epsilon$ & $154 €$ & $10 €$ & $2 \epsilon$ & $5 \epsilon$ & $10 €$ & $0 €$ & $77 €$ & $19 €$ & $7 \epsilon$ & $38 €$ & $5 \epsilon$ & $0 €$ & $902 \epsilon$ \\
\hline $\begin{array}{l}\begin{array}{l}\text { identification of raw } \\
\text { materials }\left(\mathrm{H}_{2} \mathrm{O}\right)\end{array} \\
\end{array}$ & $77 \epsilon$ & $38 €$ & $10 €$ & $10 €$ & $2 \epsilon$ & $2 \epsilon$ & $0 €$ & $0 €$ & $10 €$ & $10 €$ & $5 \epsilon$ & $38 €$ & $5 €$ & $0 €$ & $206 \epsilon$ \\
\hline \begin{tabular}{|l} 
Identification of the \\
emission source
\end{tabular} & $154 \epsilon$ & $38 €$ & $10 €$ & $10 \epsilon$ & $2 \epsilon$ & $2 \epsilon$ & $0 €$ & $0 €$ & $10 €$ & $10 €$ & $7 \epsilon$ & $38 \epsilon$ & $5 €$ & $0 €$ & $285 \epsilon$ \\
\hline $\begin{array}{l}\text { Pieces designed on a } \\
\text { digital support }\end{array}$ & $384 \epsilon$ & $230 €$ & $154 €$ & $5 \epsilon$ & $2 \epsilon$ & $10 €$ & $0 \epsilon$ & $0 €$ & $10 €$ & $77 €$ & $7 \epsilon$ & $38 €$ & $5 €$ & $0 €$ & $921 \epsilon$ \\
\hline $\begin{array}{l}\text { Description of the } \\
\text { techonologies planned } \\
\text { and other techniques }\end{array}$ & $154 \epsilon$ & $77 \epsilon$ & $5 \epsilon$ & $10 €$ & $2 \epsilon$ & $2 \epsilon$ & $0 \epsilon$ & $0 €$ & $10 €$ & $19 €$ & $5 \epsilon$ & $38 €$ & $5 \epsilon$ & $0 €$ & $326 \epsilon$ \\
\hline \begin{tabular}{|l|} 
Description of the \\
prevention, valuation \\
and compliance \\
measures
\end{tabular} & $230 €$ & $38 €$ & $5 \epsilon$ & $10 €$ & $2 \epsilon$ & $2 \epsilon$ & $0 €$ & $0 €$ & $10 €$ & $19 €$ & $7 \epsilon$ & $19 €$ & $5 \epsilon$ & $0 €$ & $347 \epsilon$ \\
\hline \begin{tabular}{l|}
$\begin{array}{l}\text { Description of the } \\
\text { measures planned for the } \\
\text { monitoring of the } \\
\text { emissions to the } \\
\text { environment }\end{array}$ \\
\end{tabular} & $154 \epsilon$ & $77 \epsilon$ & $10 €$ & $10 €$ & $2 \epsilon$ & $2 \epsilon$ & $0 €$ & $0 €$ & $10 €$ & $19 €$ & $7 \epsilon$ & $19 €$ & $5 \epsilon$ & $0 €$ & $314 \epsilon$ \\
\hline $\begin{array}{l}\text { Data for usage of hydric } \\
\text { resources }\end{array}$ & $77 \epsilon$ & $19 €$ & $5 €$ & $5 €$ & $2 \epsilon$ & $2 \epsilon$ & $0 €$ & $0 €$ & $10 €$ & $5 €$ & $7 \epsilon$ & $38 €$ & $5 €$ & $0 €$ & $174 \epsilon$ \\
\hline $\begin{array}{l}\text { Data concerning the fate } \\
\text { of efluents }\end{array}$ & $38 €$ & $10 €$ & $2 \epsilon$ & $2 \epsilon$ & $2 \epsilon$ & $2 \epsilon$ & $0 €$ & $0 €$ & $5 \epsilon$ & $5 \epsilon$ & $7 \epsilon$ & $10 €$ & $5 \epsilon$ & $0 €$ & $88 €$ \\
\hline $\begin{array}{l}\text { Data concerning the fate } \\
\text { of animals cadavers }\end{array}$ & $38 €$ & $10 €$ & $2 \epsilon$ & $2 \epsilon$ & $2 \epsilon$ & $2 €$ & $0 €$ & $0 €$ & $5 €$ & $5 €$ & $7 €$ & $10 €$ & $5 €$ & $0 €$ & $88 €$ \\
\hline $\begin{array}{l}\text { Non-technical summary } \\
\text { of the previous elements }\end{array}$ & $384 €$ & $154 €$ & $19 €$ & $10 €$ & $2 \epsilon$ & $2 \epsilon$ & $0 €$ & $0 €$ & $19 €$ & $5 €$ & $7 \epsilon$ & $38 €$ & $5 €$ & $0 €$ & $645 €$ \\
\hline \begin{tabular}{|l|} 
Registry of the \\
environmental technician
\end{tabular} & $768 €$ & $384 €$ & $77 \epsilon$ & $19 €$ & $10 €$ & $10 €$ & $0 €$ & $0 €$ & $38 €$ & $77 \epsilon$ & $10 €$ & $38 €$ & $10 €$ & $0 €$ & $1.440 \mathrm{E}$ \\
\hline TOTAL & $2.918 €$ & $1.306 €$ & $461 €$ & $110 €$ & $29 €$ & $50 €$ & $10 €$ & $3.072 €$ & $365 \epsilon$ & $307 €$ & $103 €$ & $518 €$ & $72 \epsilon$ & $0 €$ & $9.322 \epsilon$ \\
\hline
\end{tabular}

102: Reavaluation of the environmental licence (alteration of facility, transmission of licence and licence renewal) - CSC

\begin{tabular}{|c|c|c|c|c|c|c|c|c|c|c|c|c|c|c|c|}
\hline \multicolumn{16}{|c|}{ 102: Reavaluation of the environmental licence (alteration of facility, transmission of licence and licence renewal) - CSC } \\
\hline $\begin{array}{l}\text { IE (Information } \\
\text { Elements): }\end{array}$ & 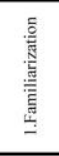 & 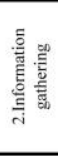 & $\sum_{m}^{\infty}$ & 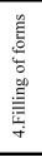 & 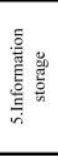 & 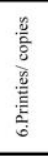 & 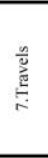 & 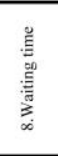 & 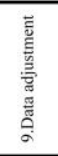 & 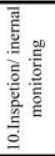 & 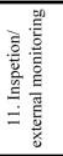 & $\begin{array}{l}\text { : } \\
\text { בั̆ } \\
\text { ב̃ }\end{array}$ & 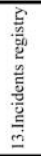 & 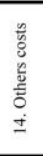 & क्ञّ \\
\hline $\begin{array}{l}\text { Base report for the } \\
\text { license request }\end{array}$ & $19 €$ & $5 €$ & $5 €$ & $5 €$ & $2 \epsilon$ & $5 €$ & $0 €$ & $768 €$ & $154 €$ & $38 €$ & $19 €$ & $29 \epsilon$ & $5 €$ & $0 €$ & $1.053 €$ \\
\hline $\begin{array}{l}\text { Description of the } \\
\text { installation and the } \\
\text { activities and conditions } \\
\text { of site }\end{array}$ & $19 €$ & $10 €$ & $5 €$ & $5 €$ & $2 \epsilon$ & $5 €$ & $10 €$ & $0 €$ & $19 €$ & $19 €$ & $19 €$ & $29 €$ & $5 €$ & $0 €$ & $146 €$ \\
\hline \begin{tabular}{|l|} 
identification of raw \\
materials $\left(\mathrm{H}_{2} \mathrm{O}\right)$ \\
\end{tabular} & $10 €$ & $5 €$ & $5 €$ & $5 \epsilon$ & $2 \epsilon$ & $2 \epsilon$ & $0 €$ & $0 €$ & $10 €$ & $10 €$ & $19 €$ & $29 €$ & $5 \epsilon$ & $0 €$ & $99 €$ \\
\hline $\begin{array}{l}\text { Identification of the } \\
\text { emission source }\end{array}$ & $10 €$ & $5 \epsilon$ & $5 \epsilon$ & $5 \epsilon$ & $2 \epsilon$ & $2 \epsilon$ & $0 €$ & $0 €$ & $10 €$ & $10 €$ & $19 €$ & $29 €$ & $5 \epsilon$ & $0 €$ & $99 \epsilon$ \\
\hline $\begin{array}{l}\text { Pieces designed on a } \\
\text { digital support } \\
\end{array}$ & $19 €$ & $19 €$ & $5 €$ & $5 \epsilon$ & $2 \epsilon$ & $2 \epsilon$ & $0 €$ & $0 €$ & $10 €$ & $10 €$ & $19 €$ & $29 €$ & $5 €$ & $0 €$ & $123 \epsilon$ \\
\hline \begin{tabular}{|l|} 
Description of the \\
techonologies planned \\
and other techniques \\
\end{tabular} & $10 €$ & $5 €$ & $5 \epsilon$ & $5 €$ & $2 \epsilon$ & $2 \epsilon$ & $0 €$ & $0 €$ & $10 €$ & $10 €$ & $19 €$ & $29 €$ & $5 €$ & $0 €$ & $99 \epsilon$ \\
\hline $\begin{array}{l}\text { Description of the } \\
\text { prevention, valuation } \\
\text { and compliance } \\
\text { measures }\end{array}$ & $10 €$ & $5 \epsilon$ & $5 €$ & $5 \epsilon$ & $2 \epsilon$ & $2 \epsilon$ & $0 €$ & $0 €$ & $10 €$ & $10 €$ & $19 €$ & $29 €$ & $5 €$ & $0 €$ & $99 €$ \\
\hline $\begin{array}{l}\text { Description of the } \\
\text { measures planned for the } \\
\text { monitoring of the } \\
\text { emissions to the } \\
\text { environment }\end{array}$ & $10 €$ & $5 €$ & $5 \epsilon$ & $5 \epsilon$ & $2 \epsilon$ & $2 \epsilon$ & $0 €$ & $0 €$ & $10 €$ & $10 €$ & $19 €$ & $29 €$ & $5 \epsilon$ & $0 €$ & $99 \epsilon$ \\
\hline $\begin{array}{l}\text { Data for usage of hydric } \\
\text { resources }\end{array}$ & $10 €$ & $5 \epsilon$ & $5 €$ & $5 \epsilon$ & $2 \epsilon$ & $2 \epsilon$ & $0 €$ & $0 €$ & $10 €$ & $10 €$ & $10 €$ & $29 €$ & $5 €$ & $0 €$ & $90 €$ \\
\hline $\begin{array}{l}\text { Data concerning the fate } \\
\text { of effluents }\end{array}$ & $5 €$ & $5 \epsilon$ & $5 \epsilon$ & $5 \epsilon$ & $2 \epsilon$ & $2 \epsilon$ & $0 €$ & $0 €$ & $10 €$ & $10 €$ & $10 €$ & $29 €$ & $5 €$ & $0 €$ & $85 €$ \\
\hline $\begin{array}{l}\text { Data concerning the fate } \\
\text { of animals cadavers }\end{array}$ & $5 €$ & $5 \epsilon$ & $5 €$ & $5 \epsilon$ & $2 \epsilon$ & $2 \epsilon$ & $0 €$ & $0 €$ & $10 €$ & $10 €$ & $10 €$ & $29 €$ & $5 €$ & $0 €$ & $85 €$ \\
\hline $\begin{array}{l}\text { Non-technical summary } \\
\text { of the previous elements }\end{array}$ & $77 \epsilon$ & $38 €$ & $5 \epsilon$ & $5 €$ & $2 \epsilon$ & $2 \epsilon$ & $0 €$ & $0 €$ & $10 €$ & $10 €$ & $19 €$ & $29 €$ & $5 €$ & $0 €$ & $200 €$ \\
\hline $\begin{array}{l}\text { Alteration of the } \\
\text { environmental technician }\end{array}$ & $384 €$ & $154 €$ & $10 €$ & $10 €$ & $10 €$ & $10 €$ & $0 €$ & $0 €$ & $19 €$ & $19 €$ & $19 €$ & $38 €$ & $10 €$ & $0 €$ & $682 €$ \\
\hline TOTAL & $586 €$ & $264 €$ & $67 €$ & $67 \epsilon$ & $29 €$ & $35 \epsilon$ & $10 €$ & $768 €$ & $288 €$ & $173 \epsilon$ & $221 \epsilon$ & $384 \epsilon$ & $67 \epsilon$ & $0 €$ & $2.958 €$ \\
\hline
\end{tabular}


Table 3: Administrative Cost for standard company - Cont.

\begin{tabular}{|c|c|c|c|c|c|c|c|c|c|c|c|c|c|c|c|}
\hline \multicolumn{16}{|c|}{ 103: Accidents, incidents and no-compliance (survey carried out by regulatory agency) - CSC } \\
\hline $\begin{array}{l}\text { IE (Information } \\
\text { Elements) }\end{array}$ & 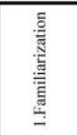 & 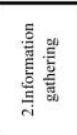 & $\sum_{m}^{\infty}$ & 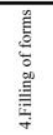 & 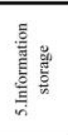 & 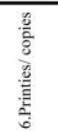 & 总 & 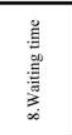 & 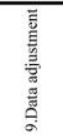 & 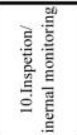 & 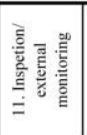 & 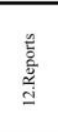 & 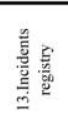 & 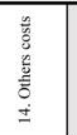 & ฮू \\
\hline $\begin{array}{l}\text { Base report for the } \\
\text { license request }\end{array}$ & $19 €$ & $5 €$ & $5 \epsilon$ & $2 \epsilon$ & $2 \epsilon$ & $5 €$ & $0 €$ & $154 €$ & $77 €$ & $19 €$ & $19 €$ & $19 €$ & $10 €$ & $0 €$ & $335 \epsilon$ \\
\hline \begin{tabular}{|l|} 
Description of the \\
installation and the \\
activities and conditions \\
of site
\end{tabular} & $10 €$ & $10 €$ & $5 \epsilon$ & $2 \epsilon$ & $2 \epsilon$ & $5 \epsilon$ & $5 \epsilon$ & $0 €$ & $10 €$ & $10 €$ & $19 €$ & $5 \epsilon$ & $5 \epsilon$ & $0 €$ & $86 €$ \\
\hline \begin{tabular}{|l|}
$\begin{array}{l}\text { identification of raw } \\
\text { materials }\left(\mathrm{H}_{2} \mathrm{O}\right)\end{array}$ \\
\end{tabular} & $5 \epsilon$ & $5 \epsilon$ & $5 \epsilon$ & $2 \epsilon$ & $2 \epsilon$ & $2 \epsilon$ & $0 €$ & $0 €$ & $5 \epsilon$ & $10 €$ & $19 €$ & $5 \epsilon$ & $5 \epsilon$ & $0 €$ & $63 \epsilon$ \\
\hline $\begin{array}{l}\text { Identification of the } \\
\text { emission source }\end{array}$ & $5 \epsilon$ & $5 \epsilon$ & $5 \epsilon$ & $2 \epsilon$ & $2 \epsilon$ & $2 \epsilon$ & $0 €$ & $0 €$ & $5 €$ & $10 €$ & $19 €$ & $5 €$ & $5 €$ & $0 €$ & $63 \epsilon$ \\
\hline $\begin{array}{l}\begin{array}{l}\text { Pieces designed on a } \\
\text { digital support }\end{array} \\
\end{array}$ & $29 €$ & $10 €$ & $5 \epsilon$ & $2 \epsilon$ & $2 \epsilon$ & $2 \epsilon$ & $0 €$ & $0 €$ & $5 €$ & $10 €$ & $19 €$ & $5 €$ & $5 \epsilon$ & $0 €$ & $92 \epsilon$ \\
\hline $\begin{array}{l}\begin{array}{l}\text { Descriptiton of the } \\
\text { techonologies planned } \\
\text { and other techniques }\end{array} \\
\end{array}$ & $5 \epsilon$ & $5 \epsilon$ & $5 \epsilon$ & $2 \epsilon$ & $2 \epsilon$ & $2 \epsilon$ & $0 €$ & $0 €$ & $5 \epsilon$ & $10 €$ & $19 €$ & $5 \epsilon$ & $5 \epsilon$ & $0 €$ & $63 \epsilon$ \\
\hline $\begin{array}{l}\text { Descriptition of the } \\
\text { prevention, valuation } \\
\text { and compliance } \\
\text { measures }\end{array}$ & $10 €$ & $5 \epsilon$ & $5 \epsilon$ & $2 \epsilon$ & $2 \epsilon$ & $2 \epsilon$ & $0 €$ & $0 €$ & $5 \epsilon$ & $10 €$ & $19 €$ & $5 \epsilon$ & $5 \epsilon$ & $0 €$ & $68 \epsilon$ \\
\hline $\begin{array}{l}\text { Description of the } \\
\text { measures planned for } \\
\text { the monitoring of the } \\
\text { emissions to the } \\
\text { environment }\end{array}$ & $19 €$ & $5 €$ & $5 \epsilon$ & $2 \epsilon$ & $2 \epsilon$ & $2 \epsilon$ & $0 €$ & $0 €$ & $5 \epsilon$ & $10 €$ & $19 €$ & $5 €$ & $5 \epsilon$ & $0 €$ & $78 €$ \\
\hline $\begin{array}{l}\text { Data for usage of hydric } \\
\text { resources }\end{array}$ & $19 €$ & $5 \epsilon$ & $5 \epsilon$ & $2 \epsilon$ & $2 \epsilon$ & $2 \epsilon$ & $0 €$ & $0 €$ & $5 \epsilon$ & $10 €$ & $19 €$ & $5 €$ & $5 \epsilon$ & $0 €$ & $78 €$ \\
\hline $\begin{array}{l}\text { Data concerning the fate } \\
\text { of effluents }\end{array}$ & $5 \epsilon$ & $5 \epsilon$ & $5 \epsilon$ & $2 \epsilon$ & $2 \epsilon$ & $2 \epsilon$ & $0 €$ & $0 €$ & $5 \epsilon$ & $5 €$ & $19 €$ & $5 \epsilon$ & $5 \epsilon$ & $0 €$ & $58 €$ \\
\hline $\begin{array}{l}\text { Data concerning the fate } \\
\text { of animals cadavers }\end{array}$ & $5 €$ & $5 €$ & $5 €$ & $2 \epsilon$ & $2 \epsilon$ & $2 \epsilon$ & $0 €$ & $0 €$ & $5 €$ & $5 \epsilon$ & $19 €$ & $5 €$ & $5 \epsilon$ & $0 €$ & $58 \epsilon$ \\
\hline $\begin{array}{l}\text { Non-technical summary } \\
\text { of the previous elements }\end{array}$ & $5 \epsilon$ & $5 €$ & $5 €$ & $5 \epsilon$ & $5 \epsilon$ & $5 \epsilon$ & $0 €$ & $0 €$ & $5 \epsilon$ & $5 €$ & $19 €$ & $5 \epsilon$ & $5 \epsilon$ & $0 €$ & $67 \epsilon$ \\
\hline TOTAL & $134 €$ & $67 €$ & $58 €$ & $31 €$ & $22 \epsilon$ & $29 \epsilon$ & $5 €$ & $154 €$ & $134 €$ & $110 €$ & $230 €$ & $72 €$ & $62 €$ & $0 €$ & $1.110 €$ \\
\hline \multicolumn{16}{|c|}{ Cost for standard company (IO1 to $\mathrm{IO} 3$ ) } \\
\hline $\begin{array}{l}\text { IE (Information } \\
\text { Elements) }\end{array}$ & 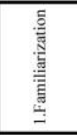 & 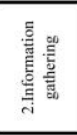 & 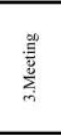 & 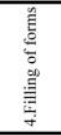 & 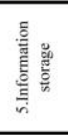 & 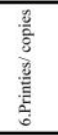 & 总 & 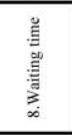 & 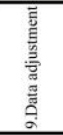 & 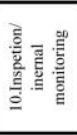 & 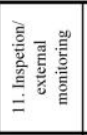 & 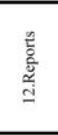 & 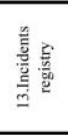 & 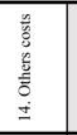 & Е్ \\
\hline TOTAL OI & $3.638 €$ & $1.637 \epsilon$ & $586 \epsilon$ & $209 \epsilon$ & $80 €$ & $114 \epsilon$ & $24 \epsilon$ & $3.994 \epsilon$ & $787 \epsilon$ & $590 €$ & $554 \epsilon$ & $974 \epsilon$ & $202 \epsilon$ & $0 €$ & $13.390 €$ \\
\hline Attivity 14 (other cost & is not provic & ed includes & ironme & technic & thers o & s servi & orage c & ormation & paper & digital & & & & $2.550 €$ & $15.940 €$ \\
\hline $\begin{array}{l}\text { cost per day } \\
\text { useful cost per day }\end{array}$ & & & & & & & & & & & & & & & $\begin{array}{r}725 € \\
91 €\end{array}$ \\
\hline
\end{tabular}


Table 4: Population time fertrapolation

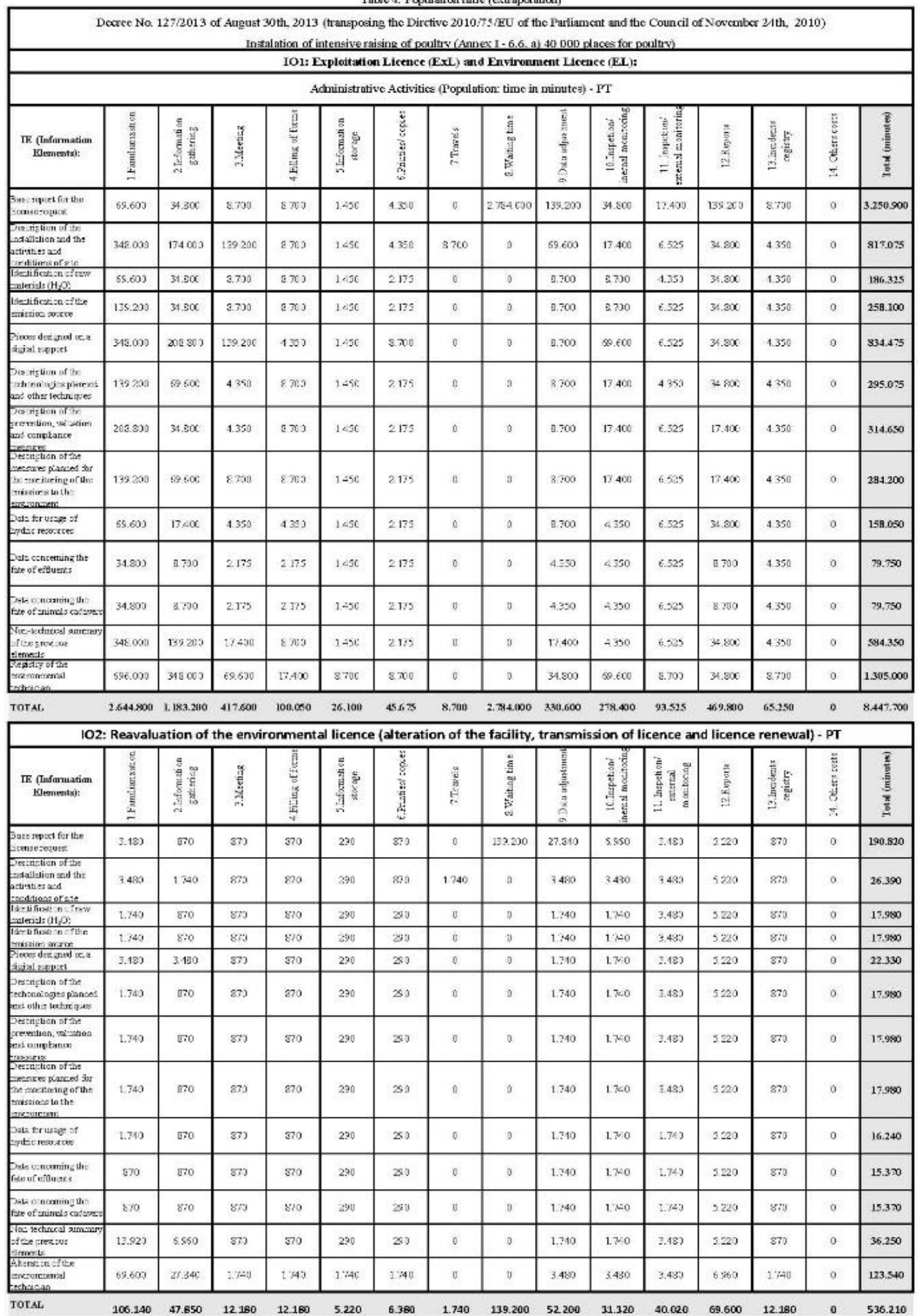


Tuble 4: Pogulation time (extrapolation) - Cont.

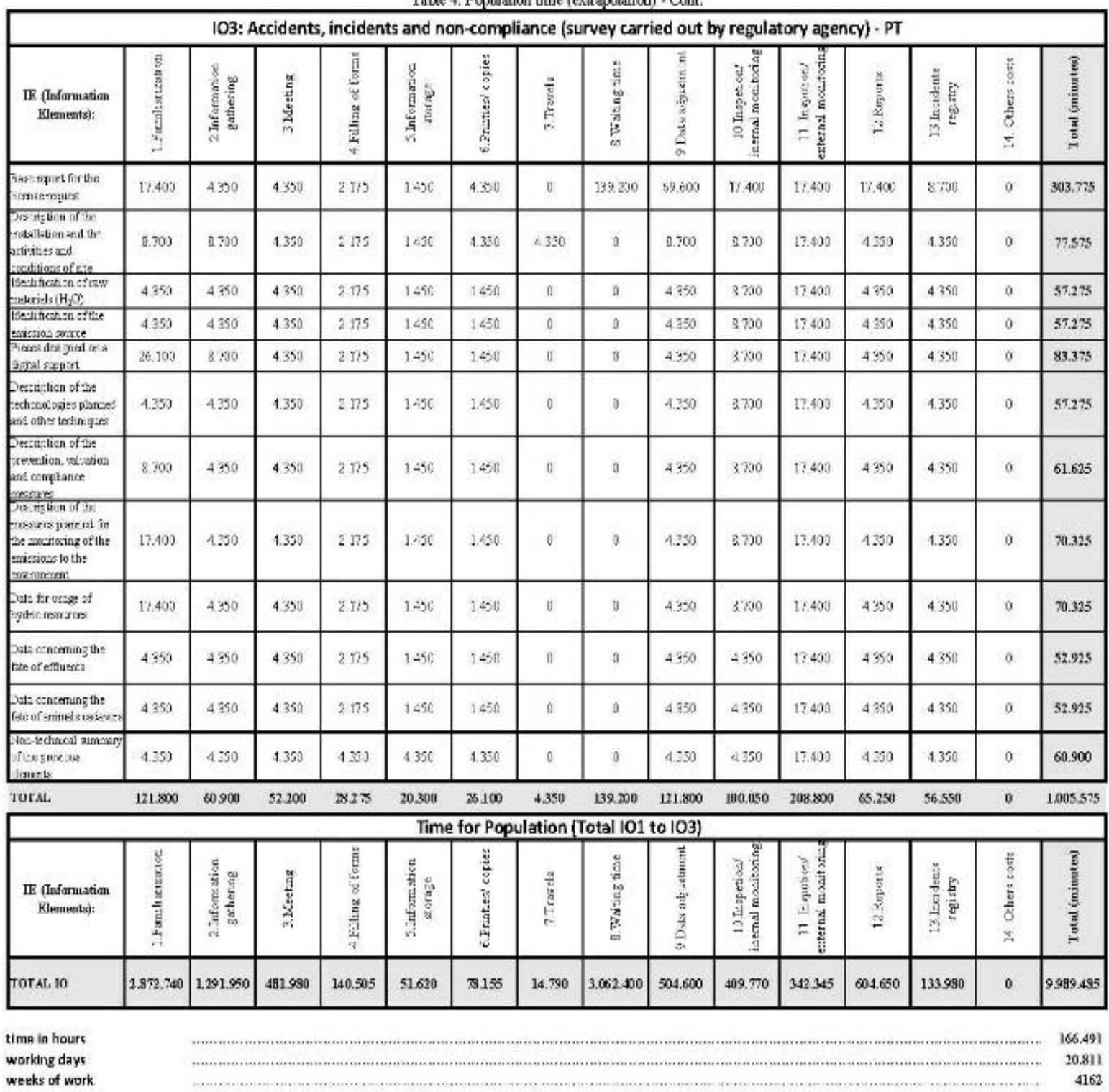




\begin{tabular}{|c|c|c|c|c|c|c|c|c|c|c|c|c|c|c|c|}
\hline \multicolumn{16}{|c|}{ 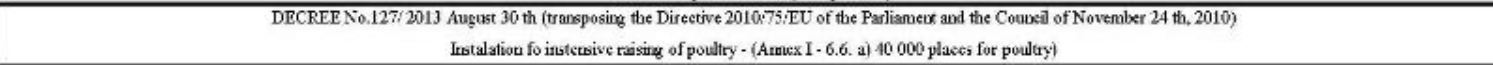 } \\
\hline \multicolumn{16}{|c|}{ 101:Kxpleitation Licence (KxL) Enviroutnental Licence $(\mathrm{KL}) \mathrm{z}$} \\
\hline \multicolumn{16}{|c|}{ Administrative Artinity (POPULATION COS T- PC) } \\
\hline 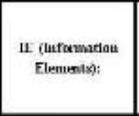 & 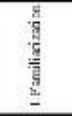 & 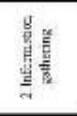 & 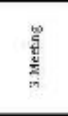 & 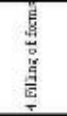 & 量 & $\begin{array}{ll}\frac{y}{2} \\
\frac{y}{2} \\
\frac{7}{2} \\
\end{array}$ & है: & 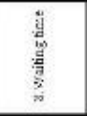 & 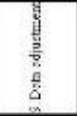 & 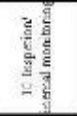 & 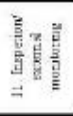 & $\begin{array}{l}\text { 曹 } \\
\text { 总 } \\
\text { ․ }\end{array}$ & 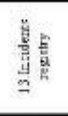 & 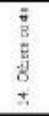 & $\stackrel{\frac{3}{3}}{5}$ \\
\hline 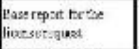 & 1113e & s1re & 1392e & $139 \div 8$ & wae & wie & ne & c454tare & $x=x+2 e$ & $\leqslant \sin 2$ & $2784:$ & $22378 \mathrm{e}$ & 1326 & oe & 52n.144r \\
\hline 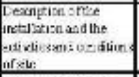 & $35.58<8$ & 278104 & $22.22 \mathrm{e}$ & $1992 \mathrm{e}$ & wie & $596 e$ & $: 3328$ & ve & 1. $1: 5 e$ & $2.34 \epsilon$ & 1.644 e & $5.56 \% \mathrm{e}$ & $695 e$ & se & 130.732f \\
\hline 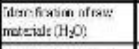 & $11.3 \mathrm{e} e$ & 53686 & $1.393 \epsilon$ & $13 n 2 e$ & wie & $3: 6$ & $0 \varepsilon$ & $0 \epsilon$ & $1392 \epsilon$ & 1.392e & $6 \% 6$ & $5.568 \varepsilon$ & 6656 & je & 20.812e \\
\hline 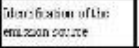 & $22.272 \epsilon$ & $55 \div 3 \mathrm{e}$ & L.392e & $1392 \mathrm{e}$ & wie & $3: \epsilon$ & $a \varepsilon$ & ve & $1392 \mathrm{e}$ & $1.992 \mathrm{e}$ & 1.6448 & $5.36 \mathrm{e} \mathrm{e}$ & $655 e$ & De & 412966 \\
\hline 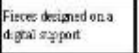 & $55.260<$ & $33.4 .8<$ & $22.22 \times$ & 6960 & aie & $: 3924$ & oe & ve & 1392. & 11.1360 & $1.11 \%$ & $5.560 \%$ & ogse & se & 133slot \\
\hline 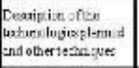 & $22.27<*$ & $11.20 \%$ & 6960 & 13960 & aie & yee & ve & ve & 19yce & 2.50 & $0,0=$ & $5.560 \%$ & byse & e & $47212 e$ \\
\hline 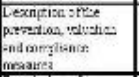 & 33.4006 & $5 s 68 \mathrm{e}$ & $696 \epsilon$ & 13926 & wie & $3: e$ & $a \varepsilon$ & ae & $1392 \mathrm{e}$ & $2.784 \varepsilon$ & $1: 548$ & $2.78+\epsilon$ & esse & se & sol.34te \\
\hline 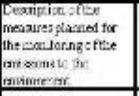 & $23.37 \mathrm{C}$ & $11.136=$ & $1.393 \mathrm{C}$ & 19226 & $m a c$ & $3: C$ & ac & oc & $1398 \mathrm{C}$ & $3.784 \mathrm{C}$ & 10446 & $2.78+C$ & wos & je & $4542 \mathrm{C}$ \\
\hline 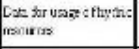 & $11.13 x$ & 2280 & 6960 & $696=$ & die & sase & uะ & ve & $139 y_{2}=$ & 0462 & $1.44 \%$ & $3.568 \%$ & oyse & ge & 2scasse \\
\hline 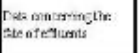 & $9.208 \mathrm{E}$ & $: 1924$ & 398र & $34:$ & die & sete & Uะ & ve & see & $090 \%$ & $1.44 *$ & $1.39: 2$ & osoe & e & $12 \pi 00$ \\
\hline 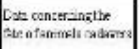 & 5.568 & : 1928 & 3ase & $34=$ & ale & $54:=$ & uะ & ve & SHe E & $0 y_{0}=$ & $1.44 \div$ & 1.39: & osse & et & 12 . xue \\
\hline 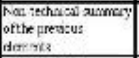 & $3568 c$ & $38272=$ & $2.78+\mathrm{C}$ & 10026 & $32: c$ & $3: c$ & $n c$ & ne & $3784 c$ & Gighe & 10445 & $5.368 \mathrm{C}$ & wore & $x$ & $824 \% 5$ \\
\hline 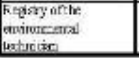 & $111.362 \mathrm{e}$ & $55 t 500$ & 11.135e & $2784 \varepsilon$ & $: .3926$ & .9528 & ae & ae & $5568 \epsilon$ & $11136 \epsilon$ & $1: 9926$ & $5.668 \varepsilon$ & 0.3726 & se & 2IS.SIBE \\
\hline TOTIL & 423.11/Re & $150.312 \mathrm{C}$ & mislae & $16 \mathrm{Mr} \mathrm{f}$ & $+17 \mathrm{ic}$ & $73 \mathrm{REC}$ & $1302 \mathrm{C}$ & 445.Aane & magre & $44 \leq 44 \mathrm{C}$ & $14.96+\mathrm{C}$ & $7 \leqslant .1 \% \mathrm{se}$ & in 4 ane & ne & Latsone \\
\hline \multicolumn{16}{|c|}{ 10 2: Reavaluation of the environmental licence (alteration of the facility, transmission of licence and licence renewal) - PC } \\
\hline $\begin{array}{l}\text { IE (Musarnuatm } \\
\text { Elenarits) }\end{array}$ & $\begin{array}{l}\frac{5}{2} \\
\frac{\pi}{2} \\
\frac{2}{5} \\
\frac{2}{2} \\
\frac{2}{4}\end{array}$ & 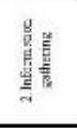 & 施 & 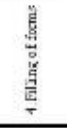 & 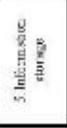 & 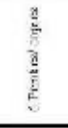 & ti & 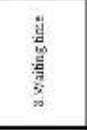 & 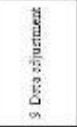 & 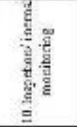 & 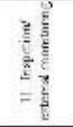 & 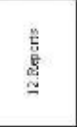 & 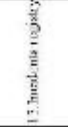 & 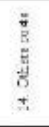 & ह3 \\
\hline Paserepst & $237 \%$ & $13 \% *$ & $19 y=$ & 139e & 40. & 13, & ve & $22 m 2 \pi$ & $\angle 49 A^{\circ}$ & 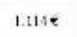 & $5: 74$ & 3598 & wye & .e & 305316 \\
\hline 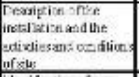 & $557 \%$ & $27:$ & 1998 & 1998 & 16e & 19: & $23:$ & oe & 557 & $35: 4$ & 558 & 355 & 12\%e & oe & $+.222 \mathrm{C}$ \\
\hline 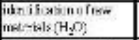 & $278 \epsilon$ & $13 ; \epsilon$ & 1396 & 1396 & 466 & $4 \varepsilon \varepsilon$ & ae & of & 2766 & $278 \varepsilon$ & 5578 & $835 \varepsilon$ & 1396 & se & $287 \pi$ \\
\hline 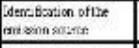 & $2 \pi x$ & $13 \times 2$ & 1396 & $139 \pm$ & ace & $4 e *$ & טะ & ve & 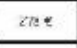 & 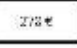 & ssse & asse & 139е & Je & 2.877 \\
\hline 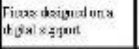 & sose & ssie & $139 e$ & 1396 & see & $4 e$ e & aะ & ne & 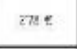 & zase & ss7e & a3s: & 139 e & ge & 35736 \\
\hline 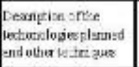 & $278 \mathrm{e}$ & $139 \mathrm{e}$ & $139 e$ & 1398 & $46 \epsilon$ & $46 \varepsilon$ & $0 \varepsilon$ & of & 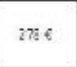 & $278 \varepsilon$ & 5578 & 835e & $199 e$ & se & $2.877 \epsilon$ \\
\hline 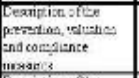 & $278 \varepsilon$ & $137 e$ & 1396 & 1399 & 468 & $16 e$ & oe & ve & me & nove & $557 \%$ & 835e & 1396 & de & 2.8776 \\
\hline 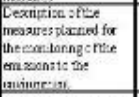 & 2785 & $13 \% t$ & $139 x$ & $139=$ & ase & $4 c=$ & uะ & ne & Cतs & The & $158=$ & ayse & nz:e & se & 2.877 \\
\hline 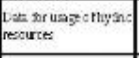 & $278 \mathrm{e}$ & $13 ; 4$ & $199 \mathrm{e}$ & 1396 & $46 e$ & $46 \div$ & ve & ve & me & noe & $2 \pi 8$ & $435 \%$ & 1938 & 26 & 1.Ssse \\
\hline 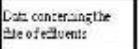 & $139 \mathrm{C}$ & $13 \% \mathrm{e}$ & 1396 & 1398 & $46 \epsilon$ & $46 e$ & $a \varepsilon$ & oe & $2 n e$ & $278 \varepsilon$ & 2788 & 8356 & 1996 & :e & 2.4soe \\
\hline 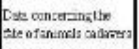 & 1998 & $13 \%$ & 1998 & 1394 & Tot & $16 \div$ & ve & ve & 270 & mee & 278 & 395e & 137e & $\alpha$ & $2.49) e$ \\
\hline 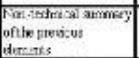 & $2.227 \varepsilon$ & $01: 48$ & $139 e$ & $139 e$ & $46 e$ & $46 e$ & $0 \varepsilon$ & oe & $m e$ & $278 \mathrm{e}$ & SSTE & $835 e$ & $139 e$ & se & ssule \\
\hline 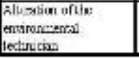 & Lu.sse e & 14:18 & $278 \%$ & $n 84$ & aie & ate & oe & oe & s5ie & $557 \%$ & 5574 & 1.11/ & $23: 4$ & de & 19. me \\
\hline
\end{tabular}




\begin{tabular}{|c|c|c|c|c|c|c|c|c|c|c|c|c|c|c|c|}
\hline \multicolumn{16}{|c|}{ 103: Acddents, Incidents, and no-compllance (survey carrled out by regulatory agency\}- PC } \\
\hline 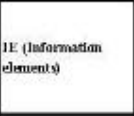 & 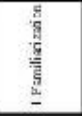 & 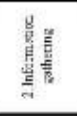 & 离 & 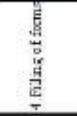 & 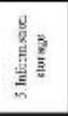 & 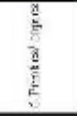 & s. & 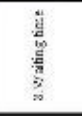 & 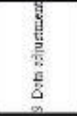 & 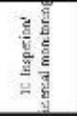 & 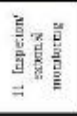 & 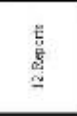 & 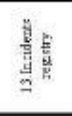 & 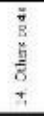 & 常 \\
\hline Paserian & 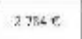 & sigere & fighe & 3ase & mae & were & ne. & $22272 \mathrm{e}$ & 1. wise & 2 गु44r & $2784 ?$ & $2 \pi=8$ & ware & te & $48004 e$ \\
\hline 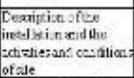 & $1.392 \mathrm{e}$ & $2352 \mathrm{e}$ & 6966 & $348=$ & aje & sace & figse & ne & $1392 \%$ & $1792 e$ & 2784 & $696 \div$ & bose & oe & 12.4126 \\
\hline 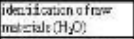 & 6960 & 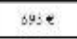 & 0962 & 3: & Det & Zue & ve & ve & 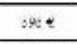 & $1.392 \varepsilon$ & $234=$ & 6960 & os:e & ex & p.101e \\
\hline 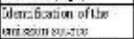 & fighe & figre & fi96e & Hse & m:e & 31:e & ne & ne & $x=8$ & $1792 \mathrm{r}$ & $2784 ?$ & 696? & fere. & ae & 8.16Ae. \\
\hline 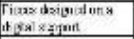 & $4.176 \mathrm{e}$ & $2: 3926$ & 690 e & $34:$ & चुरe & Zie & $0 \%$ & aE & se: & $1392 \varepsilon$ & 2784 & $696 \div$ & osset & se & $133411 e$ \\
\hline 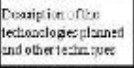 & 6968 & 5958 & 6968 & M6: & wie & wae & ve & ve & 998 & $1.392 \mathrm{e}$ & 2348 & $696 \%$ & bs:e & ae & Q.16ac. \\
\hline 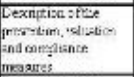 & $1.392 \%$ & $69: *$ & 6962 & 3Eะ & ale & ale & vะ & ve & 籸 & 1. $19 y_{2} t$ & $278 \%$ & $690 \%$ & osse & ce & p.sole \\
\hline 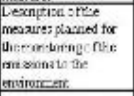 & 27846 & fige & figher & 3485 & अ:e & n:e & ne & ne & sxe? & 17928 & $3714=$ & 6986? & moe. & oe. & $11.252 \mathrm{C}$ \\
\hline 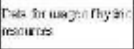 & $2.864=$ & $\Delta y_{0}=x$ & $09_{0} \mathrm{e}$ & 3a: & $\Delta=$ & Zue & טะ & ve & are & 1. $1 y_{2}=$ & 2750 & $690=$ & wose & 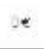 & 112526 \\
\hline 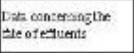 & 6968 & $69: 4$ & 6968 & rae & die & wie & oe & ve & $59<$ & 6968 & 2308 & 6968 & wase & se & $\mathrm{s} 4 \mathrm{CK} \mathrm{C}$ \\
\hline 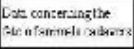 & 6960 & 6932 & 6960 & $345=$ & die & aie & "1ะ & ue & ste & 6960 & $2784=$ & 6960 & tisse & de & sasse \\
\hline 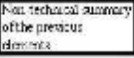 & fighic & sige & $696 \mathrm{C}$ & (i) & mec & mec & or & ne & $x<$ & 6960 & 37846 & 6in? ? & ore & oc & $8.744 \mathrm{C}$ \\
\hline & 19.4886 & 9.7446 & $8.352 \varepsilon$ & $4.524 \varepsilon$ & $3.248 \varepsilon$ & 4.1766 & 6966 & 22.2726 & $19.488 \varepsilon$ & $16.008 \varepsilon$ & $33.408 \varepsilon$ & 10.4406 & $9.048 \mathrm{E}$ & 06 & $160.892 \mathrm{f}$ \\
\hline \multicolumn{16}{|c|}{ POPULATION COST (Total IO1 to I03) } \\
\hline $\begin{array}{l}\text { 10 (Information } \\
\text { OLbigations }\end{array}$ & 葛 & 宸蓄 & ปึّ & 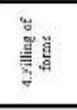 & 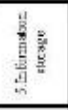 & 总 & है: & 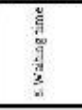 & 总势 & 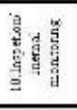 & 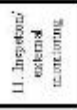 & 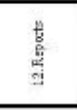 & 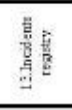 & 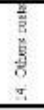 & 吾 \\
\hline TOTAL CUSTO OTS & 45unase & ma.712e & T:117e & 22.Asie & $8250 e$ & 12.5use & $2.3 m e$ & $480.984 e$ & s.73ate & assaze & $54.775 E$ & $96.745 \mathrm{e}$ & $21+437 e$ & ne & 15SK.3Ise \\
\hline
\end{tabular}

\subsection{Analysis and Discussion of the Results}

We started by interpreting the results of Tables 1 to 4 , and then we discussed the main results.

\subsubsection{Time and Cost of the "Standard Company" - Tables 2 and 3}

Through the analysis of the results, it is possible to verify that the information obligation 1 (IO1) - license of exploitation and environmental license - consumes the greatest time and cost to a standard company, when compared to the other IO. The base report for the licensing request englobes a set of elements that forces the economic operator to use other services, technical or non-technical, public or private, including the previous request of evaluation/warranty and certification of requirements that satisfy the legal demands, and the travels and time of waiting.

The necessary time for a standard poultry operator to fulfil the information obligations is 83 685 minutes (1 395 hours), which represents 174 working days (on a working schedule). The cost associated with the time spent on the administrative activities to fulfil the legal information obligations is 15940 euros, representing for the operator 725 euro/working day and 91 euros cost/working hour. In this cost are included other charges (check activity $14=2$. 550 euros) resulting from the fulfilment of legal obligations of other activities, relevant to the time, namely an environmental technician and other specialized technicians, the scanned floor plans and the storage of information elements, electronically or on paper. 


\subsubsection{Time and Cost of the Population (Extrapolation) - Tables 4 and 5}

The time and cost of the population corresponds to the extrapolation of the time and cost of the standard operator for the population. At the end of 2017, on national territory, there were 145 poultry producers with an environmental license, 29 requests of license re-evaluation / renewal were made, and 145 operators were inspected (previous requirement for licensing).

For the total population, 9989485 minutes were consumed (166 491 hours), which constitute 20881 working days (on a working schedule) and represent 4165 working weeks. The cost associated with the time for the population represents 1598318 euros, furthermore adding 1 413750 euros which represent other administrative charges, such as the more or less frequent hiring of an environmental technician and other specialized technicians, the scanning of floor plans and the storage of data, electronically or on paper. The total costs are around 3012068 euros for the poultry's population. Note that the extrapolation of the income of an environmental technician or specialist (permanently hired or only required for sporadic consulting) was done for 7 months in a year. The reason for this option is the fact that some operators are environmental technicians hired or bonded to the company (and, inclusively, some of these technicians are part of the management body), therefore, they do not have as strict and as exclusive a task for the fulfilment of the legal obligations arising from the here analysed Diploma.

From the above-mentioned analysis, we highlight that, either for the standard operator or for the extrapolation, we consider the frequencies of the administrative activities from 1 to 13 . The license renewal, under the directive's jurisdiction, is due every 10 years. Therefore, all the elements (times and costs) associated with the information obligation 1 (IO1) shall be considered in this time, not disregarding, however, the event that APA requires frequent data (for example, annually) for all the operators or for a random sample, for verification and validation of the fulfilment of the requirements subjacent to the licensing. In turn, the frequencies that should be considered for the information obligation 2 (license re-evaluation alteration / update), as well as for the information obligation 3 (inspections done) derive from article 19 concerning the facilities' alteration and article 30 concerning monitoring. The monitoring requirements are defined by APA and, in number 12 of the art. 30, it is mentioned that the groundwater and soil monitoring shall be done every 5 to 10 years. Concerning the frequency of the facilities' alteration (art. 19), an exact temporal period cannot be provided, even though it is considered that the annual extrapolation for the population is exaggerated.

Furthermore, the information obligation 3 (IO3) should include the accidents/ incidents occurrences, nevertheless APA has mentioned zero occurrences. Therefore, only the inspections done were accounted for here.

\subsubsection{Discussion of the Results}

The Standard Cost Model (SCM) is a really useful and practical tool for the assessment of the administrative charges suffered by the companies for the legal fulfilment of the information obligations. However, the quality of the results does not only depend on the methodological tools used. The background, which in this case is the law (or event), shall, according to the 
regulatory principles of quality and efficiency, obey principles of legibility and easy understanding (perception) for the targeted population; indeed, the logistic principles that embraced the first initiatives of the regulatory reform. Now, the actions and activities shall be clearly identified and defined, as well as their sequential flow. It happens that the flow of the activities necessary for the fulfilment of the legal obligations by the operator is not easy to understand. The law does not identify the number of inputs and outputs, the actions sequence and the involved public authorities. For this purpose, the investigators resorted to the privileged data of the operators and drew an orientation of the administrative activities which led to the EL (check fig. 3) obtainment. In the picture, it is possible to see the arrival and onset of data and the public institutions which intervene in the licensing process. In the same picture, the average waiting time per entity which intervenes in the deciding process of the license is mentioned. According to the estimate provided by the poultry operators, this time is about 12 months (1 financial year). If we pay attention to the average time of obligations fulfilment (IO1 to IO3) determined for the "standard company", the total time corresponds to about 8 months for the performance of the administrative activities. Obviously, here, we are faced with biases concerning the information gathered from the operators. These gaps are justified by the imprecision of the time recording for each of the activities. We can assume that it is always an estimate. The operator hardly can tell with precision the exact time that his/her employee, or himself/herself, has spent on the fulfilment of the provision of mandatory data. It would be easier to precisely tell the time waited to obtain a licensing, because this is a situation of "non-compliance" risk. On the other hand, we can also assume that the waiting time can be related to information gaps between regulatory authorities (or the ones which monitor the licensing process) or between authorities and the operator, and that it results in lengthy processes due to the attainment of further clarifications or, as a result, in decisions constrained by time. We also highlight the obligatory information provided by the operator; the regular information that the operator is forced to provide to certain public authorities is not explained in the law. Table 7 shows us the periodic mandatory information for public authorities to monitor the environmental licensing. In this chart, we observe the various electronic platforms made available to speed up the provision of information. Regarding this point, it remains to mention the possibility of overlap of the information that is distributed through the different platforms and responsible organisms. And here, the e-government, as a speed and process alignment tool and as a practical tool for the reformation and modernization of the public administration, may not have had, in certain situations, the desired effects (i.e., costs' simplification and reduction).

Table 7. Poultry Company: Periodicity of obligation information

\begin{tabular}{l|l|l}
\hline Date & Information & Periodicity \\
\hline $\begin{array}{l}\text { January } \\
31^{\text {st }}\end{array}$ & Hydric resources tax at the platform SNIRTURH* & Annual \\
\hline March $31^{\text {st }}$ & $\begin{array}{l}\text { Waste Registry on MIRR (integrated map of waste } \\
\text { registry) }\end{array}$ & Annual \\
\hline April 30 & Environmental Report to APA platform (integrated & Annual \\
\hline June $15^{\text {th }}$ & $\begin{array}{l}\text { Single form at the SIRADA } \\
\text { registry system) }\end{array}$ & $\begin{array}{l}\text { Water consumption to the Regulatory Agency - } \\
\text { APAree-month } \\
\text { period }\end{array}$ \\
\hline
\end{tabular}


*SNIRTURH - national information system of water resource use.

Source: economic operator.

\section{LICENSE OF EXPLOITATION / ENVIRONMENTAL LICENSE- Decree no. 127/2013, of August 30th}

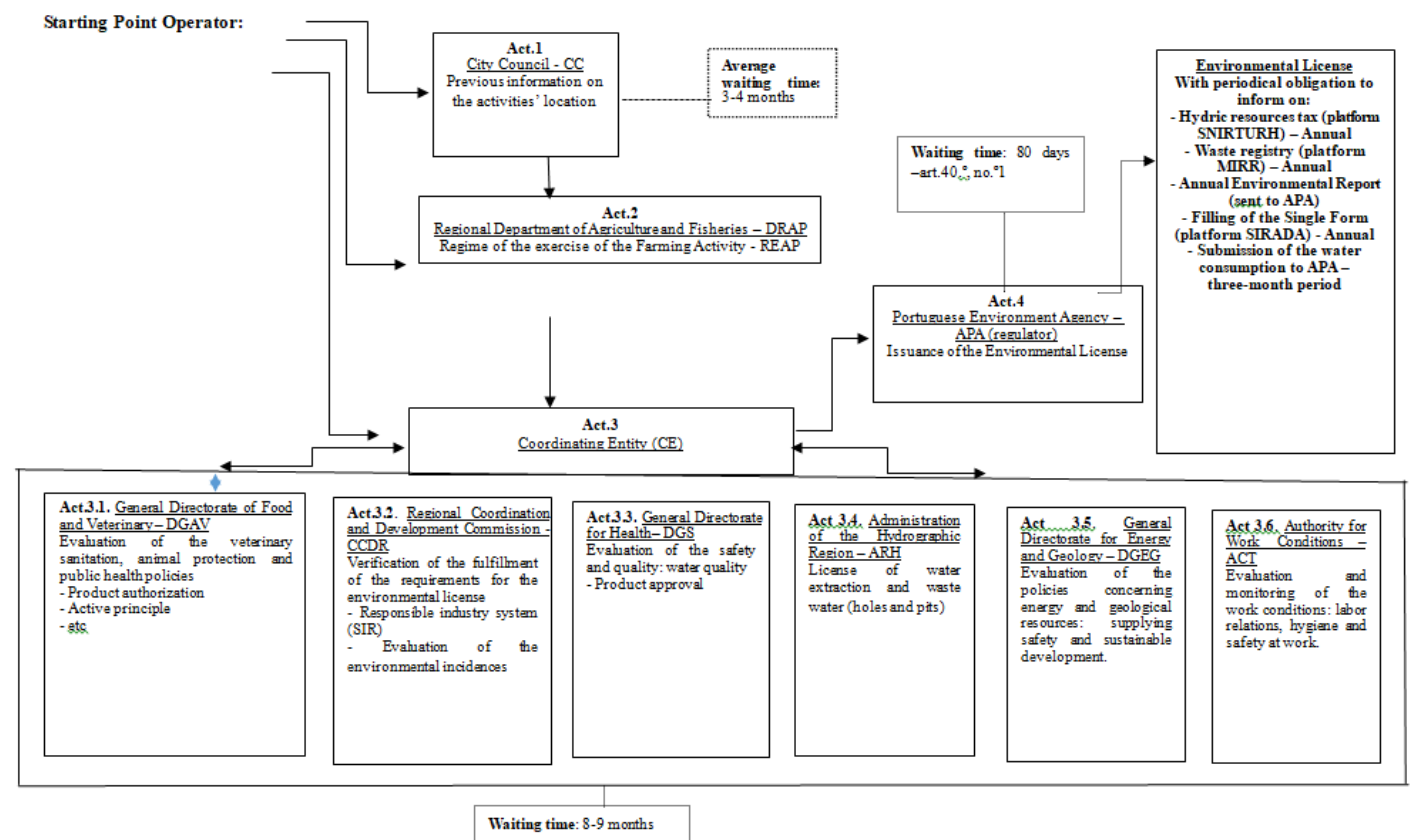

Figure 3. Timeline of the administrative activities necessary for getting the Environmental License by the economic operator

\section{Conclusion}

We conclude with some notes on the environmental policy, the administrative costs for the companies and the desideratum of the regulatory reform on the primacy of quality and efficiency of the law which, generally, are here summarized:

First, from the emphasis on the regulatory quality, effectiveness and efficiency as the primacy of the regulatory reform, the empirical studies here presented indicate that the administrative costs arising from the fulfilment of the reporting formalities are expensive to the companies, compromising the efficiency and effectiveness of the law.

Second, a certain complexity in the interpretation of the environmental law and in the lack of clarity of the information circuits between the public authorities and between these and the operator can create accrued times for the fulfilment of the legal obligations involved on the regulatory process, particularly when getting the license. An emphasis on the creation of the law through the regulation approach would be convenient and recommended. Therefore, the process management approach is suggested; especially, the reengineering of processes or their quality, to avoid the overlap of channels and speed up the information flow, thus avoiding unnecessary charges on "lost" or duplicated information and on time losses between channels.

Third, the e-government, as measure of regulatory simplification, speeds up the procedures for starting an activity, contributing to the growth of new companies and to the reduction of 
administrative charges for the companies. However, the existence of many electronic platforms per regulatory authority involved in the verification and monitoring of the normative conditions can have an adverse effect on the companies. On the one hand, the computerized systems tend to reduce the time and costs dedicated to the formalization of obligations, but on the other hand, they can multiply and overlap the information required by the companies.

Fourth, the evaluation of the regulatory impact shall obey the ex-ante and ex-post cycle as recommended by the international bodies (i.e., EU and OECD). Nevertheless, the most common practice in Portugal is the ex-post analysis and the SCM methodology. A prognostic of the impact of the law would avoid unnecessary charges for the Administration and for the companies, charges that would no longer be indemnified.

Finally, we refer to the unavailability of the public access to national or international reports on costs-benefits of the regulatory policy. Even though the advantages to the public interest are enumerated, the associated costs are unknown, which compromises the transparency of the regulatory acts and the improvement of the quality that could be inspired on the benchmarking.

\section{Acknowledgement}

The research was supported by Portuguese national funds through FCT - Fundação para a Ciência e Tecnologia, under project UID/CPO/00713/2013.

\section{References}

AMA (undated). Practical guide for administrative burdens according to the methodology Standard Cost Model - Manual PT CSM. Agency for Administrative Modernization, Office of the Secretary of State for Administrative Modernization. (in Portuguese)

Arndt, C., Baker, C. B., Querbach, T., \& Schultz, R. (2015). 2015 indicators of regulatory policy and governance: Design, methodology and key results. OECD Regulatory Policy Working Paper, 1. OECD Publishing.

Backlund, A. K. (2009). Impact Assessment in the European Commission - a system with multiple objectives. Environment Science \& Policy, 12(8), 1077-1087. https://doi.org/10.1016/j.envsci.2009.04.003

Creswell, J. W. (1994). Research Design: qualitative \& quantitative approaches. Thousand Oaks, CA, US: Sage Publications.

Decision no. 1600/2002/EC of the European Parliament and the Council of June $22{ }^{\text {nd }}, 2002$. European Commission, [Online] Available: https://eur-lex.europa.eu/legal-content/PT/TXT/?uri=CELEX:32002D1600.

Decree no. $127 / 2013$ of August $30^{\text {th }}$, 2013. Portuguese law. [Online] Available: https://www.apambiente.pt/_zdata/Instrumentos/Licenciamento\%20Ambiental/DL_127_2013 _Regime_Emissoes_Industriais_PCIP.pdf. 
Directive 2010/75/EU of the European Parliament and the Council of November $24^{\text {th }}, 2010$. European Commission, [Online] Available: http://www.prtr-es.es/data/images/Nueva-DEI-EN.pdf.

EC (2000). European Council of Lisbon, 23 and 24 March, Presidency conclusions. [Online] Available: http://www.europarl.europa.eu/summits/lis1_en.htm

EC (2002). Better Lawmaking 2002, $10^{\text {th }}$ Report from the Commission. COM (2002) 715 final, 11 December, 2002. EU Commission. [Online] Available: http://aei.pitt.edu/38400/

EC (2004). The Standard Cost Model - A framework for defining and quantifying administrative burdens for business. International Working Group on Administrative Burdens. European Commission, August, 2004.

EC (2006). Measuring administrative cost and reducing administrative burdens in the EU MEMO/06/425, European Commission, Brussels, 14 de November, 2006. [Online] Available: http://europa.eu/rapid/press-release_MEMO-06-425_en.htm?locale=en.

EC (2015). Better Regulation for Better Results - An EU Agenda. Communication from the Commission to the European Parliament, the Council, the European Economic and Social Committee and the Commission of Regions. European Commission, SWD (2015) 110 final and SWD (2015) 111 final. Strasbourg, 19 May, 2015. [Online] Available: http://ec.europa.eu/smart-regulation/better_regulation/documents/com_2015_215_en.pdf

EC (2017a). Completing the Better Regulation Agenda: Better solution for better results. Communication from the Commission to the European Parliament, the Council, the European Economic and Social Committee and the Committee of the Regions. European Commission (COM 2017-651 final), Strasbourg, 24.10.2017.

EC (2017b). Actions to Streamline Environmental Reporting. Report from the Commission to the Parliament, the Council, the European Economic and Social Committee and the Committee of the Regions. European Commission, (COM 2017 - 312 Final), Brussels, 9.6.2017.

GEP-MTSSS (2017). Income and working hours Survey - 2016. Annual Report. Office of Strategy and Planning, Minister of Labor, Solidarity and Security, ISSN (0873-6189). (in Portuguese)

INE (2016). Agriculture Statistics 2015. Instituto Nacional de Estatística - Statistics Portugal, Edição 2016. (in Portuguese)

INE (2018). Boletim mensal da Agricultura e Pescas. Instituto Nacional de Estatística Statistics Portugal, Maio, 2018.

Levi-Faur, D. (2010). Regulation \& Regulatory Governance. Jerusalem papers in regulation and governance, working paper no.1. Department of Political Science \& The Federmann School of Public Policy \& Government. The Hebrew University, Jerusalem, Israel.

Marques, M. L. (2017). The State intervention in the economy. In M. Manuela L:M:, Maria 


\section{Macrothink}

Journal of Public Administration and Governance

ISSN 2161-7104

2018, Vol. 8, No. 3

Elisabete R., \& Pedroso, J. (Eds.), Introduction to Law Manual (pp.211-264). Coimbra: Almedina. (in Portuguese)

MG (2001). Mandelkern Group on better regulation - final report. [Online] Available: http://ec.europa.eu/smart-regulation/better_regulation/documents/mandelkern_report.pdf MITSloan (2011). Sustainability: the 'embracers' seize advantage. Second annual Sustainability \& Innovation Global Executive. MITSloan Management Review, Feb. 10, 2011.

OECD (1995). Recommendation of the OECD Council on improving the quality of government regulation.

[Online]

Available:

https://legalinstruments.oecd.org//instruments?mode=advanced\&reference $=\mathrm{C}(95) 21 \sim 2 \mathrm{FFINAL}$

OECD (2012). Recommendation of the Council on Regulatory Quality and Governance. [Online] Available: https://www.oecd.org/governance/regulatory-policy/49990817.pdf

OECD (2015). OECD Regulatory Policy Outlook 2015. Paris: OECD Publishing. https://doi.org/10.1787/empl_outlook-2015-en

OEDC (1997). Regulatory Impact Analysis - Best practices in OECD countries. [Online] Available: https://www.oecd.org/gov/regulatory-policy/35258828.pdf

Renda, A., Schrefler, L., Luchetta, G., \& Zavatta, R. (2013). Assessing the cost and benefits of regulation. Study for European Commission, Secretariat General - Final Report. Brussels, 10 December.

Smith, D., Erbacci, A., \& Kauffmann, C. (2016). Promoting inclusive growth through better regulation: the role of regulatory impact assessment. OECD Regulatory Policy Working papers n.3. OECD Publishing. https://doi.org/10.1787/5jm3tqwqp1vj-en

Torriti, J., \& Ike, E. (2015). Administrative cost of regulation and foreign direct investment: the Standard Cost Model in non-OECD countries. Review of World Economy, 151, 127-144. https://doi.org/10.1007/s10290-014-0200-y

WBG (2015). Doing Business 2015: Going Beyond Efficiency. World Bank Group: A World Bank Group Flagship Report.

WBG (2016). Doing Business 2015: Measuring Regulatory Quality and Efficiency. World Bank Group: A World Bank Group Flagship Report.

Yin, R. K. (1994). Discovering the future of the case study method in evaluation research. $\begin{array}{llll}\text { American of Journal 283-290. } & \text { Evaluation, }\end{array}$ https://doi.org/10.1177/109821409401500309

\section{Copyright Disclaimer}

Copyright for this article is retained by the author(s), with first publication rights granted to the journal.

This is an open-access article distributed under the terms and conditions of the Creative Commons Attribution license (http://creativecommons.org/licenses/by/4.0/). 